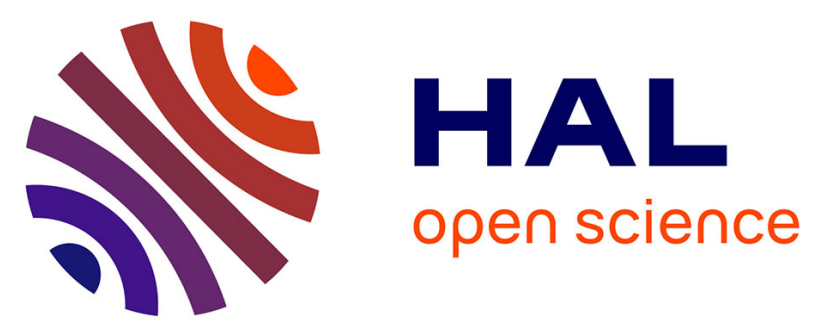

\title{
Insights into shallow magma storage and crystallization at Volcán Llaima (Andean Southern Volcanic Zone, Chile)
}

Caroline Bouvet de Maisonneuve, M. Dungan, Olivier Bachmann, Alain Burgisser

\section{To cite this version:}

Caroline Bouvet de Maisonneuve, M. Dungan, Olivier Bachmann, Alain Burgisser. Insights into shallow magma storage and crystallization at Volcán Llaima (Andean Southern Volcanic Zone, Chile). Journal of Volcanology and Geothermal Research, 2012, 211-212, pp.76-91. 10.1016/j.jvolgeores.2011.09.010 . insu-00630420

\section{HAL Id: insu-00630420 \\ https://hal-insu.archives-ouvertes.fr/insu-00630420}

Submitted on 10 Oct 2011

HAL is a multi-disciplinary open access archive for the deposit and dissemination of scientific research documents, whether they are published or not. The documents may come from teaching and research institutions in France or abroad, or from public or private research centers.
L'archive ouverte pluridisciplinaire HAL, est destinée au dépôt et à la diffusion de documents scientifiques de niveau recherche, publiés ou non, émanant des établissements d'enseignement et de recherche français ou étrangers, des laboratoires publics ou privés. 


\title{
Insights into shallow magma storage and crystallization at Volcán Llaima (Andean Southern Volcanic Zone, Chile)
}

\author{
C. Bouvet de Maisonneuve ${ }^{a^{*}}$, M.A. Dungan ${ }^{a}$, O. Bachmann ${ }^{b}$, A. Burgisser ${ }^{c}$ \\ ${ }^{\text {a }}$ University of Geneva, Earth and Environmental Sciences Section, 13 rue des Maraichers, 1205 Geneva, \\ Switzerland (aroline.bouvet@unige.ch, michael.dungan@unige.ch) \\ * corresponding author: caroline.bouvet@unige.ch, tel: +41(0) 2237966 60, fax: +41(0) 223793210 \\ ${ }^{\mathrm{b}}$ University of Washington, Earth and Space Sciences, Seattle, WA 98195-1310, USA \\ (bachmano@u.washington.edu)
}

c ISTO, CNRS-University of Orleans, 45071 Orleans, France (burgisse@cnrs-orleans.fr)

10-Oct-11 


\section{Abstract}

Scoriae produced by four mafic historic eruptions of Volcán Llaima are used to elucidate magma differentiation, recharge, mixing, and eruption triggering. Whole-rock, mineral, and olivine-hosted melt inclusion chemistry suggest that basaltic andesites $\left(\sim 52-53.5 \mathrm{wt} . \% \mathrm{SiO}_{2}\right)$ stall at immediately sub-edifice depths ( $\leq 4 \mathrm{~km}$ beneath the base of the volcano), where they crystallize to large extents and form mush bodies. Melt inclusion trends overlap with the whole-rock data trends defined by the entire volcano up to 53-55\% $\mathrm{SiO}_{2}$, but more evolved compositions define divergent trends for some elements, with up to 2.2 wt $\% \mathrm{TiO}_{2}$ (increasing $\mathrm{Zr}$ ) and $\mathrm{Al}_{2} \mathrm{O}_{3}$ as low as $12.5 \mathrm{wt} \%$ (decreasing $\mathrm{Sr}$ ) at $57-58 \mathrm{wt} \% \mathrm{SiO}_{2}$. These more evolved melt compositions are inferred to be the result of shallow evolution of interstitial melt during the formation of crystal mush bodies, as a consequence of degassing and crystallization with a reduced participation of Fe-Ti-oxides. The inferred suppression of Fe-Ti-oxide stability and the modal dominance of plagioclase crystallization are consistent with low fluid-saturation pressures of $~ 40-70 \mathrm{MPa}$ inferred from average $\mathrm{H}_{2} \mathrm{O}$ contents for mafic arc magmas (dominantly 1-4 wt\%) but low $\mathrm{CO}_{2}$ contents (dominantly 0-300 ppm) in melt inclusions. The broad range in olivine core compositions $\left(\mathrm{Fo}_{69-83}\right)$ and the absence of correlated degassing and magma evolution trends in historic Llaima magmas suggest that they are stored as multiple dike-like bodies created by a high frequency of magma replenishment relative to the frequency of large eruptions. This temporal-spatial disconnection leads to isolated evolution and degassing of discrete magma batches, followed by remobilization and assembly just prior to eruption. Eruptions are probably triggered by recharge of relatively hot, mafic, and much less degassed magma, in accord with dominantly reversely-zoned olivine crystals, and higher olivine-melt temperatures recorded by the relatively primitive matrix glasses and coexisting olivine rims.

Keywords: Magma storage, Degassing, Crystallization, Melt Inclusions, Strombolian activity 


\section{Introduction}

Volcán Llaima $\left(38.7^{\circ} \mathrm{S}\right)$ is located in the Southern Volcanic Zone of the Andes, about $700 \mathrm{~km}$ to the south of Santiago de Chile (Fig. 1). It is one of the most active volcanoes in Chile, with over 50 eruptions since $\sim 1640$ AD. Although the explosivity of its eruptions is generally not sufficient to cause lethal hazards at significant distances from the cone (for example, the nearest town of Melipeuco $18 \mathrm{~km}$ from the summit), the eruptions can cause significant economic and social disruption due to the destruction of infrastructure by lahars or closure of the national park in which the volcano is located. Even relatively minor eruptive events, such as the Strombolian paroxysms in January, 2008 and April, 2009, create hazards due to the presence of near-summit glaciers, which are highly susceptible to melting and lahar generation during vigorous fountaining.

Volcán Llaima displays a variety of eruptive behaviors. Violent-Strombolian paroxysms, as on January 1, 2008, often mark the onset of sporadic but prolonged eruptive activity (1-5 years). Paroxysms terminate within hours to a few days and the activity shifts to smaller explosions that typically occur at regular intervals (10-60 minutes), as is observed at Stromboli Volcano, Italy (Metrich et al., 2010; Metrich et al., 2001; Rosi et al., 2000 and references therein), and last over days or weeks. Lava extrusion may follow explosive activity, and these lavas can be voluminous (e.g. 1955-1957, up to $\sim 0.5-0.8 \mathrm{~km}^{3}$ based on the thickness and extent of the lava flows). Lavas are the dominant volumetric fraction of erupted magma during the rapid construction of the late Holocene Llaima edifice ( $\leq 3-5 \mathrm{ka})$. Passive degassing with no magma extrusion (Kazahaya et al., 1994; Shinohara, 2008) frequently occurs between periods of eruptive activity.

Assessing shifts in eruptive styles is crucial for volcanic hazard assessments, and is only possible by identifying how and where magmas are stored beneath the volcano and understanding the triggering mechanisms of eruptions. By combining whole-rock, mineral, and melt inclusion chemistry, we show that magmas at Llaima are stored as crystal mush at very shallow depths where they undergo degassing during crystallization. They probably are stored as many individual batches in a complex of anastamosing dikes. 
Eruptions are triggered by the injection of hotter and more mafic magma, which amalgamates contributions from multiple batches just prior to eruption. Magma recharge is essential for long-term eruptive activity, and a high frequency of recharge events is evidently at the root of the 'hyperactive' nature of Volcán Llaima, where the average recurrence interval of eruptive activity has been $~ 5.6 \mathrm{yrs}$ since the beginning of the reliable, high-resolution historical record ( 1850 AD; Dzierma and Wehrmann, 2010).

\section{Eruptive history and studied samples}

The Llaima edifice can be divided into three stages of eruptive activity (Fig. 1; Naranjo and Moreno, 2005). The first and oldest is dominantly effusive, with the construction of the pre-Holocene edifice by lava flows, basaltic-andesitic to dacitic in composition. The eruptive behavior then switched to a period of explosive activity around $13 \mathrm{ky}$ before present with the eruption of a large mafic ignimbrite, the deposits of which can be found up to $20 \mathrm{~km}$ from the inferred source. This second era ended around $9.5 \mathrm{ky}$ before present with the Plinian eruption of the most evolved (dacitic) magma found at Llaima. The volcano subsequently shifted to a period of cone-forming, less explosive activity with the eruption of numerous lava flows of basalt to basaltic-andesite, associated with Strombolian activity. In this study we focus on the youngest manifestations ( 1850-2008 AD) of the latest stage of cone-building activity.

Four tephra units from the latest Historic eruptions were selected in order to constrain the magma storage conditions and depths over the last 150 years at Volcán Llaima. The tephra units selected were: (1) the 2008 tephra, (2) the 1957 tephra, (3) the upper and (4) the lower tephra layers of the Fissural 3 eruption, which has been dated at $\sim 1850 \mathrm{AD}$ by one ${ }^{14} \mathrm{C}$ age. The 2008 and 1957 eruptions are products of the central summit vents, whereas the Fissural 3 ( 1850 AD) eruption is from the northeastern terminus of a series of two lower-flank fissures on the northeastern flank (Fig. 1). 
The 2008 eruption began 'tentatively' in May, 2007, but this episode ramped up dramatically on January 1, 2008 with the sudden onset of a violent Strombolian eruption ( 12 hrs), which produced the sampled tephra. The eruptive activity then diminished significantly in vigor and minor explosive activity continued through 2008 and part of 2009, with some repose periods. Lava flows were produced in January-February and July, 2008, and then again after the early April, 2009 paroxysm. The 1957 eruption lasted two years (1955-57) and produced three voluminous lava flows on the northern, northeastern, and eastern flanks of the volcano (Fig. 1). Little is known about the temporal evolution of the eruption, but only one tephra unit could be stratigraphically linked to this eruption, and it must correspond to a paroxysm. The Fissural 3 ( 1850 AD) eruption occurred from two parallel chains of cones on the northeastern flank of the volcano. Related tephra directly underlie the 1957 tephra layer. Two locally thick tephra layers ("lower" and "upper") could be traced back to the two sets of cones. Voluminous lava flows are associated with the younger set of cones, and are covered with tephra. The studied eruptions produced basaltic andesites (Tables 1 and 2) containing about 15-35 vol\% plagioclase, 1-4 vol\% olivine, and minor clinopyroxene (Fig. 2). Scoriae are generally less crystalline (up to 20-35 vol\% phenocrysts) than the subsequent lava flows (up to 55 vol\% phenocrysts).

\section{Analytical methods}

Mafic scoriae 2-5 cm in diameter were collected from two proximal stratigraphic sections located to the northeast of the volcano (in the direction of prevailing winds, Fig. 1). Samples were gently crushed and olivines were hand-picked under a binocular microscope from the $>0.5 \mathrm{~mm}$ size fraction. These olivines were mounted in epoxy and polished. Three textural categories of glass were analyzed (Fig. 3a): (1) closed melt inclusions in olivine cores that were isolated from the host melt, (2) open melt inclusions, which consist in embayments at the olivine rims, and (3) matrix glasses attached to olivine grains. Melt inclusions analyzed are at least $40 \mu$ in diameter and reported EPMA, SIMS and LA-ICP-MS measurements correspond to single analyses within an inclusion. Experimental reheating of the inclusions 
before analysis was not necessary, as only glassy melts were analyzed. Melt inclusions containing vapor bubbles were avoided for $\mathrm{H}_{2} \mathrm{O}$ and $\mathrm{CO}_{2}$ analysis (except two inclusions which contained a small shrinkage bubble) to ensure accurate measurements of volatile contents. Whole-rock major and trace element compositions of the tephra and the associated lava flows were obtained by X-ray fluorescence analyses at the University of Lausanne (UNIL; Switzerland).

Major element analyses by electron microprobe were performed on glasses ( 280 analyses for 185 closed melt inclusions, 42 open melt inclusions, and 50 matrix glasses; including $\mathrm{S}$ and $\mathrm{Cl}$ ) and $\sim 150$ host olivines (JEOL 8200 electron microprobe at UNIL). Glasses were analyzed with a $15 \mu \mathrm{m}$ diameter beam, and variable beam currents: $\mathrm{K}$ and $\mathrm{Na}$ were analyzed first at $2 \mathrm{nA}, \mathrm{Cl}, \mathrm{S}$, and $\mathrm{P}$ were analyzed last at 30 $\mathrm{nA}$ and the other major elements were analyzed in between at $10 \mathrm{nA}$. A combination of glass and mineral standards was used. Counting time was 8/4 s (peak/background) for $\mathrm{K}$ and $\mathrm{Na}, 10 / 5 \mathrm{~s}$ for $\mathrm{Si}$ and $\mathrm{Al}$, and 20/10 s for the other elements. Host olivines were analyzed at $40 \mathrm{nA}$ with a focused beam, and simple four to six point zoning profiles were obtained for all of them. The relative error on major elements is around $2 \%$ for $\mathrm{SiO}_{2}, \mathrm{Al}_{2} \mathrm{O}_{3}$ and $\mathrm{CaO}, 3 \%$ for $\mathrm{FeO}$ and $\mathrm{MgO}, 10 \%$ for $\mathrm{TiO}_{2}, 15 \%$ for $\mathrm{K}_{2} \mathrm{O}, 35 \%$ for $\mathrm{Na}_{2} \mathrm{O}$, and $40 \%$ for $\mathrm{MnO}$.

$\mathrm{H}_{2} \mathrm{O}$ and $\mathrm{CO}_{2}$ contents in $\sim 120$ of the glasses analyzed for major elements were measured by secondary ion mass-spectrometry (SIMS) using a CAMECA ims-6f at Arizona State University (ASU; USA). Gold-coated samples were bombarded by a $20 \mu \mathrm{m}$ diameter primary beam of ${ }^{16} \mathrm{O}^{-}$ions, with a 10 nA current, following the technique described in Pan et al. (1991). The analysis area was pre-sputtered for four minutes to remove surface contamination. Counting cycles were $5 \mathrm{~s}$ for both $\mathrm{H}_{2} \mathrm{O}$ and $\mathrm{CO}_{2}$, and single analyses are average values of 10 to 30 cycles. Secondary ion intensities were normalized to ${ }^{18} \mathrm{O}$ and converted to weight concentrations using a basaltic standard with well established $\mathrm{H}_{2} \mathrm{O}$ and $\mathrm{CO}_{2}$ concentrations (synthesized by Gordon Moore and Kurt Roggensack at ASU and Torsten Vennemann at UNIL; Table 3). Only FTIR measurements were considered for the $\mathrm{H}_{2} \mathrm{O}$ and $\mathrm{CO}_{2}$ contents of the standards. Errors were obtained from counting statistics, and precision within an analysis session is 
generally on the order of $\pm 8 \%$ (Pan et al., 1991). Background signals for ${ }^{1} \mathrm{H}$ and ${ }^{12} \mathrm{C}$, converted to weight percent $\mathrm{H}_{2} \mathrm{O}$ and ppm $\mathrm{CO}_{2}$, are $0.25-0.73 \mathrm{wt} \%$ and 20-40 ppm respectively, as measured on nominally volatile-free olivine hosts. High background signals due to epoxy degassing under vacuum (although the epoxy was carefully selected) were not problematic relative to measured $\mathrm{H}_{2} \mathrm{O}$ and $\mathrm{CO}_{2}$ contents. Reported data are background corrected.

Trace element abundances in $\sim 150$ of the studied glass inclusions were analysed by laser ablation inductively coupled plasma mass-spectrometry (LA-ICPMS) at UNIL, using an UP193-FX ArF $193 \mathrm{~nm}$ excimer ablation system (New Wave Research, USA) interfaced to an Element XR sector field ICPMS (ThermoFisher Scientific, Germany). Operating conditions of the laser included an on-sample fluence of $4.7 \mathrm{~J} / \mathrm{cm}^{2}, 5 \mathrm{~Hz}$ repetition rate and $25-50 \mu \mathrm{m}$ pit sizes. Helium was used as a cell gas. The acquisition times for the background and the ablation interval amounted to $\sim 70$ and $40-60 \mathrm{~s}$, respectively. All isotope masses were scanned using four acquisition points per peak, the mass window having been set at $20 \%$ of

the peak width. Dwell times per point were $5 \mathrm{~ms}$ for ${ }^{42} \mathrm{Ca},{ }^{88} \mathrm{Sr}$ and ${ }^{137} \mathrm{Ba}$ and $10 \mathrm{~ms}$ for other isotopes. The $\mathrm{ThO}^{+} / \mathrm{Th}^{+}$and $\mathrm{Ba}^{++} / \mathrm{Ba}^{+}$ratios were optimised to $\sim 0.1 \%$ and $2.0 \%$, respectively. The NIST 612 synthetic glass was used for external standardisation. The average element abundances were taken after Pearce et al. (1997). ${ }^{42}$ Ca served as an internal standard. Intensity vs. time data were reduced using SILLS (Guillong et al., 2008).

\section{Assessing post-entrapment modification}

Prior to interpretation as recorders of magmatic processes, melt inclusions must be assessed with regard to the possibility that their compositions have been modified by secondary or post-entrapment processes. Such processes include boundary-layer melt entrapment during crystal growth, post entrapment crystallization (or melting) of the inclusion walls, FeO loss by coupled Fe-Mg diffusion through the host, and water loss by proton or molecular diffusion through the host olivine. These processes have been 
addressed in detail by Danyushevsky et al. (2000, 2002a, and 2002b) and a review of the ways to test for and correct them can be found in Kent (2008).

Diffusion-related chemical boundary layers may form in melt surrounding rapidly grown crystals due to the consumption of compatible elements and the exclusion of incompatible elements by the crystallizing mineral. If modified boundary-layer melt is trapped as a melt inclusion, it will not be representative of the host magma composition. Boundary layer entrapment has been shown to be negligible for melt inclusions larger than $50 \mu \mathrm{m}$ (Lu et al., 1995), which is the case for the vast majority of the melt inclusions analyzed in this study. In addition, we detect no correlation between melt inclusion diameter and $\mathrm{Mg \# ,} \mathrm{Fe-} \mathrm{or} \mathrm{Mg-content} \mathrm{(Fig.} 1$ in supplementary material). We infer that diffusion-related boundary layer processes did not significantly affect these melt inclusions.

Post-entrapment modification of a melt inclusion by equilibration with the host crystal will affect its composition. Assessing equilibrium between melt inclusions and their olivine hosts requires knowledge of the oxidation state of the melt at the time of entrapment (i.e. the exact $\mathrm{FeO}$ content of the melt inclusion). Due to the absence of analyzable Fe-Ti-oxide pairs in Llaima magmas, we do not have good constraints on their oxidation states. Melt inclusions analyzed in this study define a good positive correlation between the Mg\# of the inclusion and the Fo content of the olivine, suggesting equilibrium, but they appear to span a range in oxidation states between QFM and NNO (Fig. 4). This could either represent a real variability of the oxidation state of the melt inclusion population due to variable degrees of degassing (loss of some $\mathrm{S}$ species such as $\mathrm{H}_{2} \mathrm{~S}$ would cause oxidation of the melt; Kelley and Cottrell, 2009), or the spread could be due to post-entrapment crystallization or melting of inclusion walls, which would shift the inclusions away from equilibrium in opposite directions.

Post-entrapment melting of inclusion walls is a process that has not yet been invoked in melt inclusion studies, but we believe it could be occurring in Llaima magmas due to their shallow storage at relatively low temperatures, and their interaction with hotter recharge magmas just prior to eruption, as discussed 
below. For simplicity, we chose to consider that the studied melt inclusions were in equilibrium with the olivine hosts at an oxygen fugacity of NNO. Any deviation from equilibrium was attributed to either postentrapment crystallization (PEC, max 7 vol\%) or post-entrapment melting (PEM, max 5 vol\%; Table 1 in supplementary material). To attest the reliability of this approach, the same procedure was repeated for an assumed oxygen fugacity of QFM. This yielded minimally different results (max 8 vol\% PEC and 4 vol\% PEM; Table 1 in supplementary material). Initial compositions of inclusions that were not in equilibrium with the host olivine were recalculated by incremental $(0.01 \mathrm{wt} \%)$ addition or removal of olivine to the inclusion until achieving equilibrium with the host mineral, using the PETROLOG 2.1 software (Danyushevsky et al., 2002a). The amount of post-entrapment modification experienced by the most affected of these inclusions has a negligible effect on all elements other than $\mathrm{Fe}$ and $\mathrm{Mg}$, and sometimes Si. All data shown in figures and discussed in the text are corrected values considering an oxygen fugacity of $\mathrm{NNO} . \mathrm{H}_{2} \mathrm{O}-\mathrm{CO}_{2}$-saturation pressures were calculated using the post-entrapment corrected values of volatile contents.

Melt inclusions may also be affected by diffusive exchange with the host olivine; i.e. Fe loss by coupled Fe-Mg exchange, and/or water gain or loss by proton or molecular diffusion through the host, at relatively short timescales (Danyushevsky et al., 2002a; Gaetani and Watson, 2002; Hauri, 2002; Portnyagin et al., 2008). Fe loss was tested for on a plot of total $\mathrm{Fe}(\mathrm{FeO} *)$ versus $\mathrm{MgO}$ by comparing the melt inclusion data to the whole-rock data (Fig. 5). Fe-loss would move the melt inclusion data vertically downwards, below the whole-rock trend. Since this is not the case here, we infer that no Fe was lost. Water diffusion is more difficult to evaluate. Water exchange by proton diffusion between the matrix melt and the melt inclusion is rapid and accommodated by a change in the oxidation state of the inclusion (Danyushevsky et al., 2002a). Vacancy diffusion through olivine was observed to occur on similarly fast time scales (Gaetani et al., 2009), promoting rapid re-equilibration of the melt inclusion oxidation state with the ambient, and therefore leaving no sign of water re-equilibration. In the case of Llaima, the low $\mathrm{CO}_{2}$ contents in melt inclusions strongly imply entrapment at shallow depths, since the migration of $\mathrm{CO}_{2}$ 
through host minerals (apart from fractures) is generally considered to be of no consequence. Shallow magma storage and crystallization is also suggested by the mineral assemblage and element fractionation trends, as discussed below. Considering that the melt inclusions were trapped at relatively shallow depths, we do not believe that they experienced much re-equilibration of their $\mathrm{H}_{2} \mathrm{O}$ contents, because they probably have not travelled much - if at all - between the level of entrapment and the level of storage prior to eruption. The consequences of such minor re-equilibration, a slight under-estimation of the $\mathrm{H}_{2} \mathrm{O}-\mathrm{CO}_{2}$ saturation pressure, would not change the interpretation below.

\section{Results}

\subsection{Melt inclusions and their olivine hosts}

Olivine crystals are generally euhedral to subhedral. Some crystals are broken, others are slightly rounded or resorbed, but the main deviation from euhedral shapes is due to crystals aggregating to each other and merging into one grain with a complex shape (Fig. 3b or d). Very thin melt films persist between some grains, enabling us to identify individual crystals in the aggregate. Most olivines host a few large inclusions and/or embayments (Fig. 3a and d), but some crystals contain numerous small wormy inclusions often containing small vapor bubbles (Fig. 3e and f). These crystals probably reveal complex histories of repeated crystallization/melting cycles, as observed at Stromboli (Metrich et al., 2010; Metrich et al., 2001). Closed melt inclusions are rounded, wormy, or inverse crystal shapes (Fig. 3g-i). Small euhedral plagioclase crystals were found inside a few inclusions (Fig. 3c). Embayments are either long, narrow tubes or rounded inclusions that remained in communication with the external melt via a 'bottleneck' (Fig. 3j-k). Matrix glass usually contains small plagioclase microlites (Fig. 31), except between two closely neighboring crystals.

Four to six point zoning traverses across olivine host crystals (Fig. 6a) record diverse core compositions and zoning trends in each sample, with cores ranging from $\mathrm{Fo}_{84-67}$. It is difficult to define an 
“equilibrium" population. Rim compositions span a slightly narrower range $\left(\mathrm{Fo}_{81-75}\right)$, focused around $\mathrm{Fo}_{78-}$ ${ }_{80}$ in all four units (Fig. 6b). Zoning profiles record non-zoned, normally zoned, and reversely zoned olivines. Reversely-zoned olivines seem to be the most common.

\subsection{Major elements}

Whole-rock compositions of the four studied units cluster in a narrow range of compositions around evolved basalt to basaltic andesite. The glasses define larger ranges in composition from slightly more mafic up to andesite, with $\mathrm{SiO}_{2}$ contents ranging from 49-57 wt\% compared to 51-54 wt $\%$ for the wholerock analyses (Fig. 7, Table 2, Table 1 in supplementary material). The melt inclusion data for the four units overlap with each other and with the whole-rock data from the entire volcano up to $\sim 53.5 \mathrm{wt} \% \mathrm{SiO}_{2}$. More evolved melt inclusions diverge from the whole-rock trend towards lower $\mathrm{Al}$ and higher Ti contents (down to 13 wt $\% \mathrm{Al}_{2} \mathrm{O}_{3}$ and $>2 \mathrm{wt} \% \mathrm{TiO}_{2}$ compared to $16 \mathrm{wt} \% \mathrm{Al}_{2} \mathrm{O}_{3}$ and 1.4-1.6 wt $\% \mathrm{TiO}_{2}$ in $\mathrm{Llaima}$ andesitic magmas with $56 \mathrm{wt} \% \mathrm{SiO}_{2}$ ). The most evolved compositions are represented by closed melt inclusions, whereas the open melt inclusions and matrix glasses are closer to whole-rock compositions. Similar observations can be made from plots of total $\mathrm{Fe}\left(\mathrm{FeO}^{*}\right.$ ) versus $\mathrm{MgO}$ (Fig. 5), where closed melt inclusions are in equilibrium with rather evolved olivines (down to $\mathrm{Fo}_{71}$ ), whereas open melt inclusions and matrix glasses are in equilibrium with less evolved olivine compositions ( $\mathrm{Fo}_{77}$ or greater), and wholerocks with even less evolved olivine compositions (up to $\mathrm{Fo}_{83}$ ). There are no systematic differences between the studied units.

Temperature was estimated on the basis of $\mathrm{Mg}$ partitioning for each glass analyzed, using the olivineliquid thermometer of Beattie (1993). This thermometer can be used without an olivine composition, as it retrieves the temperature at which a liquid would become saturated with olivine at a given pressure (50 $\mathrm{MPa}$ in our case). However, it does not take into account the amount of $\mathrm{H}_{2} \mathrm{O}$ dissolved in the melt, and therefore overestimates the temperature of all the closed melt inclusions and part of the open melt inclusions. Medard and Grove (2008) developed an expression to correct temperatures for the presence of $\mathrm{H}_{2} \mathrm{O}$ in the melt. We used this expression for melt inclusions in which $\mathrm{H}_{2} \mathrm{O}$ contents were measured in 
order to evaluate the temperature overestimation of the Beattie (1993) thermometer. Without considering the effect of dissolved $\mathrm{H}_{2} \mathrm{O}$ in the melt, closed melt inclusions display a relatively wide range in temperatures from $\sim 1000^{\circ} \mathrm{C}$ to $\sim 1170^{\circ} \mathrm{C}$, whereas matrix glass temperatures cluster around $1130-1170^{\circ} \mathrm{C}$ similarly to open melt inclusions (Fig. 8). When correcting the temperature for the presence of dissolved $\mathrm{H}_{2} \mathrm{O}$ in the melt, closed and open melt inclusion temperatures are lowered by $60-110^{\circ} \mathrm{C}$ and range from $\sim 900-1100^{\circ} \mathrm{C}$ for the closed melt inclusions and $\sim 1000-1100^{\circ} \mathrm{C}$ for the open melt inclusions. Matrix glasses being essentially degassed, their temperatures remain globally unchanged. These matrix temperatures, however, may not be representative of pre-eruptive temperatures because $\mathrm{H}_{2} \mathrm{O}$ was lost upon eruption and not prior to eruption. In order to more accurately compare melt inclusion and matrix temperatures, we chose to consider the temperature distribution on an $\mathrm{H}_{2} \mathrm{O}$-free melt basis.

\subsection{Volatiles}

Llaima glasses have $\mathrm{H}_{2} \mathrm{O}$ contents of $0-4 \mathrm{wt} \%$ (one outlier at $4.4 \mathrm{wt} \%$; Fig. 9, Table 1 in supplementary material), and low $\mathrm{CO}_{2}$ contents of 0-400 ppm (one outlier at $511 \mathrm{ppm}$ ). Matrix glasses are degassed, but open inclusions usually still contain $\mathrm{H}_{2} \mathrm{O}$ and $\mathrm{CO}_{2}$, in some cases as much as in closed inclusions. $\mathrm{H}_{2} \mathrm{O}-\mathrm{CO}_{2}$-saturation pressures were estimated with the model of Papale et al. (2006), wherein $\mathrm{FeO}$ and $\mathrm{Fe}_{2} \mathrm{O}_{3}$ were recalculated for an oxygen fugacity buffered at NNO. Strikingly low entrapment pressures are obtained, primarily due to low $\mathrm{CO}_{2}$ contents. These rarely reach values of $100 \mathrm{MPa}$, and only a few inclusions indicate pressures up to $150 \mathrm{MPa}$ (Fig. 10). Assuming an average density of $2200 \mathrm{~kg} / \mathrm{m}^{3}$ (Finn and Williams, 1982) and a volume of $\sim 250 \mathrm{~km}^{3}$ for the volcanic edifice (a right circular cone $\sim 2.4$ $\mathrm{km}$ high and $\sim 10 \mathrm{~km}$ in radius at its base), the pressure at the base of the edifice is on the order of $18 \mathrm{MPa}$. Estimated $\mathrm{H}_{2} \mathrm{O}-\mathrm{CO}_{2}$-saturation pressures thus yield shallow entrapment depths of 0-4 km below the base of the edifice with only a few inclusions recording depths approaching $6 \mathrm{~km}$. Only the 1957 inclusions seem to define a coherent degassing trend over a large range of pressures. $\mathrm{H}_{2} \mathrm{O}$ and $\mathrm{CO}_{2}$ contents do not correlate with major element concentrations (coefficients of determination from linear regressions, $\mathrm{R}^{2}<$ 
0.2; Table 4, Fig. 11), nor do $\mathrm{H}_{2} \mathrm{O}-\mathrm{CO}_{2}$-saturation pressures correlate with a fractionation index such as $\mathrm{K}_{2} \mathrm{O}\left(\mathrm{R}^{2} \leq 0.1\right.$, except maybe for the 1957 inclusions; Table 4, Fig. 10).

Sulfur and Chlorine contents (up to $1300 \mathrm{ppm} \mathrm{Cl}$ and $1500 \mathrm{ppm} \mathrm{S}$; Table 1 in supplementary material) are in the range of values observed at many arc volcanoes (up to $2000 \mathrm{ppm} \mathrm{Cl}$ and $2500 \mathrm{ppm} \mathrm{S}$; Wallace, 2005). They are weakly positively correlated with each other $\left(R^{2}=0.3-0.4\right.$; Fig. 12), but are strongly correlated when normalized to a fractionation index such as $\mathrm{K}_{2} \mathrm{O}\left(\mathrm{R}^{2} \geq 0.6\right)$. The $\mathrm{S} / \mathrm{Cl}$ ratio varies negatively with $\mathrm{K}_{2} \mathrm{O}$, suggesting that $\mathrm{S}$ is preferentially degassed as the magma evolves, as previously suggested by Sisson and Layne (1993). No simple correlations can be defined between $\mathrm{S}$ or $\mathrm{Cl}$ and $\mathrm{H}_{2} \mathrm{O}$ or $\mathrm{CO}_{2}$

Some closed melt inclusions display very low $\mathrm{S}$ (even below detection limit) but $\mathrm{H}_{2} \mathrm{O}, \mathrm{CO}_{2}$, and $\mathrm{Cl}$ contents that are not anomalous. Careful examination of these inclusions revealed healed cracks from which S and small amounts of the other volatiles may have leaked out of the inclusion prior to or during eruption. S, therefore, could be a good proxy for assessing volatile leakage through cracks. Twenty-six of the studied inclusions have been compromised by volatile leakage. Their major and trace element compositions have been kept in the data set, although their volatile contents were excluded.

\subsection{Trace elements}

We focus on $\mathrm{Sr}$ and $\mathrm{Zr}$ contents and ratios to evaluate crystallization processes, $\mathrm{Zr}$ being an incompatible element and Sr being a compatible element in plagioclase (the dominant crystallizing phase at Llaima). Sr contents of the glasses range from 330-590 ppm, and $\mathrm{Zr}$ contents range from 50-150 ppm. $\mathrm{Sr} / \mathrm{Zr}$ ratios vary over a large range (from 2-10) and are strongly correlated with both $\mathrm{TiO}_{2}$ and $\mathrm{Al}_{2} \mathrm{O}_{3}$ (Fig. 13, Table 2, Table 1 in supplementary material). The trends defined by the four units overlap, and are mainly defined by closed melt inclusion populations. $\mathrm{Sr} / \mathrm{Zr}$ ratios of open melt inclusions and matrix glasses are identical and define a narrower range (3.5-7), similar to the whole-rock $\mathrm{Sr} / \mathrm{Zr}$ ratios (4.5-7). 
Whole-rocks, however, display slightly higher $\mathrm{Al}_{2} \mathrm{O}_{3}$ and lower $\mathrm{TiO}_{2}$ contents than the matrix glass and open melt inclusions.

\section{Discussion}

\subsection{Magma storage}

Major elements, trace elements, and volatile contents all suggest that Llaima magmas are stored at immediately sub-edifice depths. Glass compositions extend the whole-rock trend toward lower $\mathrm{Al}$ and higher Ti contents (Fig. 7). Major element models of a fractionation trend leading to the combination of high $\mathrm{TiO}_{2}$ (suppression of FeTi-oxide stability) and anomalously low $\mathrm{Al}_{2} \mathrm{O}_{3}$ (expansion of plagioclase stability at the expense of ferromagnesian phases) support extensive crystallization and degassing at shallow storage depths, in relatively dry conditions. Trace elements (e.g. Sr/Zr) record the same conditions. The trend toward low $\mathrm{Sr} / \mathrm{Zr}$ and the strong correlation of this ratio with $\mathrm{Al}_{2} \mathrm{O}_{3}$ and $\mathrm{TiO}_{2}(\mathrm{Sr} / \mathrm{Zr}$ increasing with $\mathrm{Al}_{2} \mathrm{O}_{3}$ and decreasing with $\mathrm{TiO}_{2}$; Fig. 13) are consistent with voluminous plagioclase crystallization and suppression of FeTi-oxide stability during shallow magma evolution. Due to the high plagioclase contents of Llaima magmas, and the absence of FeTi-oxides, whole-rock compositions are shifted towards higher $\mathrm{Al}_{2} \mathrm{O}_{3}$ and lower $\mathrm{TiO}_{2}$ contents relative to glasses with the same $\mathrm{Sr} / \mathrm{Zr}$. Finally, extremely low $\mathrm{H}_{2} \mathrm{O}-\mathrm{CO}_{2}$-saturation pressures around 40-70 MPa are recorded by the melt inclusions (Figs. 9 and 10). In conclusion, a significant fraction of erupted Llaima magmas has been stored at depths as shallow as $0-4 \mathrm{~km}$ below the base of the edifice.

The closed melt inclusion trend toward low $\mathrm{Sr} / \mathrm{Zr}$ and the strong correlation of this ratio with $\mathrm{Al}_{2} \mathrm{O}_{3}$ and $\mathrm{TiO}_{2}$ is reproduced by a simple Rayleigh fractionation model (FC; Fig. 13b). Olivine and plagioclase were assumed to crystallize in proportions 1:9, and the distribution coefficients used for crystallization modeling are reported in Table 5. By modeling the melt inclusion composition trend, we are not looking at a true fractional crystallization process in which crystals are physically separated from the liquid, but 
rather at the evolution of the interstitial liquid composition during crystallization. Up to $55 \mathrm{wt} \%$ crystallization (i.e. $54 \mathrm{vol} \%$ crystallization considering densities of $2640 \mathrm{~kg} / \mathrm{m}^{3}, 2680 \mathrm{~kg} / \mathrm{m}^{3}$, and 3320 $\mathrm{kg} / \mathrm{m}^{3}$ for the liquid, plagioclase and olivine respectively) is required to reproduce the composition of the most evolved melt inclusions from the least evolved liquid composition (highest $\mathrm{Sr} / \mathrm{Zr}$ ), which may have already experienced some crystallization. These maximum crystallinities are higher than crystallinities observed for the tephra (up to 30 vol\% crystals). Assimilation could have been taking place during magma storage and crystallization, as suggested by a U-series study conducted on Llaima magmas (Reubi et al., 2011). To ensure assimilation is not significantly affecting the $\mathrm{Sr} / \mathrm{Zr}$ ratios or the amount of crystallization implied, we calculated an assimilation-fractional crystallization (AFC) trend, following the method of DePaolo (1981). We considered the assimilation of $10 \mathrm{wt} \%$ of a granite from the surroundings (Table 5; Lucassen et al., 2004), and kept all the other parameters identical to the FC model. The AFC trend almost overlaps with the FC trend, yielding similarly high amounts of crystallization (up to $55 \mathrm{wt} \% \sim 54$ vol\%; Fig. 13b) and implying once more that magmas at Llaima are stored in a highly crystalline state. Storage at high crystallinity is consistent with thermal models of magma reservoirs that imply extended residence at $\geq 50-60$ vol\% crystals (Huber et al., 2009; Koyaguchi and Kaneko, 1999). The fact that magmas are not eruptible at crystal contents $\geq 55-60$ vol\% (e.g., (Marsh, 1981; Vigneresse et al., 1996) implies some magma remobilization process prior to eruption, and is in agreement with the lower crystal fractions measured in the erupted products.

The prolongation of the whole-rock trend by evolved melt inclusion compositions is defined primarily by the closed melt inclusion population (Fig. 7), which includes compositions that are not representative of any erupted magma. We infer that the closed inclusions represent the evolved interstitial liquid produced by extended fractional crystallization of magma during the formation of a mush. This is in agreement with: (1) The observation of a high volume fraction of plagioclase crystallization. (2) The widespread occurrence at Llaima of very crystal-rich erupted mafic magmas, particularly as lava flows (up to 55 vol\% crystals). (3) The observation of olivine and olivine-plagioclase multi-crystal aggregates, 
wherein solid-solid grain boundaries suggest that they were highly concentrated during storage and that they were evolving toward completely solid intrusions. And (4) the presence of small euhedral plagioclase crystals inside open melt inclusions (Fig. 3c) which have the same evolved compositions as the closed melt inclusions without such plagioclase crystals. The latter observation also implies that crystals were densely packed prior to eruption.

We call particular attention to the divergence of the evolved extension of the melt inclusion trend from the Llaima whole-rock trend and emphasize that the melt inclusions with the highest $\mathrm{TiO}_{2}$ and lowest $\mathrm{Al}_{2} \mathrm{O}_{3}$ (at 56-58 wt.\% $\mathrm{SiO}_{2}$ ) do not correspond to any erupted andesitic magma compositions. Such melts may be present in many crystal-rich Llaima magmas as mixing components related to immediately preeruptive crystal mush remobilization, but their exceptional compositions strongly support the conclusion that they formed as interstitial liquids during mush formation at shallow depths ( $\leq 4 \mathrm{~km}$ beneath the base of the edifice), rather than in volumetrically significant magma chambers wherein crystals were being physically separated from eruptible volumes of evolved magmas.

Melt inclusion populations from single eruptive events do not seem to record magma evolution along single-stage ascent and decompression paths. $\mathrm{H}_{2} \mathrm{O}$ and $\mathrm{CO}_{2}$ contents in melt inclusions do not correlate systematically with any major or trace element index of progressive magma evolution (Fig. 11, Table 4). $\mathrm{H}_{2} \mathrm{O}-\mathrm{CO}_{2}$ degassing trends are not observed (except perhaps for the 1957 unit; Fig. 9), and $\mathrm{H}_{2} \mathrm{O}-\mathrm{CO}_{2}-$ saturation pressures do not correlate with a fractionation index such as $\mathrm{K}_{2} \mathrm{O}$ (Fig. 10). Pressure (first boiling) is the primary factor controlling dissolved $\mathrm{H}_{2} \mathrm{O}-\mathrm{CO}_{2}$ contents; variations in temperature and crystallinity (and hence melt composition) for the four units studied are not significant enough to affect the solubilities. One way of explaining the general lack of correlated degassing and magma evolution trends is to consider magma storage in multiple dike-shaped bodies (Fig. 14). Each body has a slightly different composition, depending on its degree of crystallization amongst other parameters, but all bodies undergo degassing in a similar way (according to the vertical pressure in the dyke body). This situation would not yield a unique correlated degassing and magma evolution trend, rather as many trends as there 
are bodies. Individual trends are not distinguishable within our dataset, however we do see that at a $\mathrm{H}_{2} \mathrm{O}-$ $\mathrm{CO}_{2}$-saturation pressure of about $40-50 \mathrm{MPa}$, magmas display a range in $\mathrm{K}_{2} \mathrm{O}$ of $\sim 0.8 \mathrm{wt} \%$ suggestive of multiple sources. Interpretation of the data may be complicated by $\mathrm{CO}_{2}$ fluxing from an underlying magma undergoing degassing. However, the perspective of multiple bodies is also required by wide ranges of olivine core compositions $\left(\mathrm{Fo}_{84-67}\right.$, Fig. 6a), which can only be explained by multiple magma sources.

\subsection{Magma recharge and eruption triggering}

The high frequency of historic eruptions at Llaima (one eruption with a VEI $\geq 2$ every $\sim 5.6$ yrs years; Dzierma and Wehrmann, 2010) implies a high frequency of magma replenishment events. Magma recharge is a potential triggering mechanism, and the recharge magma is likely to be hotter and more mafic than the resident magma. Matrix glasses are commonly slightly more mafic than the closed inclusions, and associated olivine-liquid equilibrium temperatures are amongst the highest registered (1130- $1170^{\circ} \mathrm{C}$ compared to $1000-1170^{\circ} \mathrm{C}$ for the closed melt inclusions without considering the presence of dissolved $\mathrm{H}_{2} \mathrm{O}$ in the melt, Fig. 8). Olivine zoning profiles record essentially normally zoned and reversely zoned olivines (Fig 6) with reversely zoned olivines being the most common. High $\mathrm{Sr} / \mathrm{Zr}$ ratios were measured in closed melt inclusions from normally zoned olivines, which is in agreement with a hotter, less evolved recharge magma that has not experienced much crystallization. Conversely, low $\mathrm{Sr} / \mathrm{Zr}$ ratios were measured in reversely zoned olivines, which originated from the cooler, more evolved resident mush. Olivine rim compositions cluster around $\mathrm{Fo}_{78-80}(\mathrm{Fig} 6 \mathrm{~b})$ indicating assembly and partial homogenization between reversely zoned crystals originating from the cooler resident magma, and normally zoned crystals derived from the hotter recharge magma.

Little time has elapsed between recharge and eruption, as olivines have not re-equilibrated entirely with the new magma (short diffusion profiles) and a diverse olivine population is preserved in scoria samples. In contrast, open inclusions and matrix glasses have had time to homogenize. They define a narrower range in major element compositions than do closed inclusions, and form relatively tight clusters in terms 
of $\mathrm{Sr} / \mathrm{Zr}$ (Fig. 13). These have intermediate values with respect to the closed inclusion trend, and can be interpreted by diffusive mixing and homogenization of the high-Sr/Zr recharge magma with the low-Sr/Zr evolved interstitial melt in the resident mush. Equilibration of the melt composition over short time scales is possible because the diffusion of elements in melt is five to six orders of magnitude faster (diffusivity of $\mathrm{Zr}$ in melt is $\sim 10^{-10}-10^{-11} \mathrm{~m}^{2} / \mathrm{s}$; LaTourrette et al., 1996) than in crystals (diffusivity of Fe-Mg in olivine is $\sim 10^{-16} \mathrm{~m}^{2} / \mathrm{s}$; Costa et al., 2008).

A complex of anastamosing dikes (Fig. 14) would reduce heat loss in this shallow mush environment. Each new recharge would either intrude partially solidified preexisting dikes or form a new adjacent dike, or contribute to both. When recharge magmas do not act as triggers, a certain fraction of them will be trapped as partly isolated dikes within a zone of concentrated injections, and progressively evolve into mushes. This scenario would lead to the focalization of upward gas percolation through partly molten mush bodies. Remobilization through partial melting and/or mixing with a crystal-poor magma is required to decrease the crystallinity to about 30 vol\% prior to eruption as tephra, and could be explained by this process.

Volcán Llaima appears to be a strongly fault-controlled system. It displays two summit craters aligned north-south, parallel to the north-south trending Liquiñe-Ofqui fault bounding the edifice to the east. In addition, several sets of fissural vents are aligned NNE-SSW on the western flank, and east-west on the northeastern flank. Considering the geographical distribution of vents, and the range in depths suggested by the $\mathrm{H}_{2} \mathrm{O}-\mathrm{CO}_{2}$-saturation pressures recorded by melt inclusions, dike-like reservoirs at Llaima would be approximately $3-4 \mathrm{~km}$ deep, $\sim 5 \mathrm{~km}$ long and a few tens of meters wide, yielding a volume of $\sim 0.75-1 \mathrm{~km}^{3}$ per reservoir (Fig. 14). Assuming that the entirety of a reservoir is not tapped upon eruption due to higher crystallinities on the walls, magma remobilization in three to four of such reservoirs is more than sufficient to explain the observed erupted volumes (i.e. $0.5-0.8 \mathrm{~km}^{3}$ for the $1955-57$ eruption). A strongly fault-controlled conduit system would contribute to explain the observed chemical characteristics at Llaima and enhance the proposed mush remobilization scenario. Mixing of diverse magma batches, 
probably in multiple stages prior to eruption would lead to the observed range in olivine core compositions as well as the poorly correlated relations between melt compositions, volatile contents, and the entrapment pressures calculated for diverse trapped melts present in single, paroxysm-related tephra deposits.

We suggest that petrologic constraints and the historical record of activity are consistent with a high, long-term magma recharge flux consisting in part of frequent but small-volume events. These are essential to maintain the bulk reservoir of many crystal mush-filled dikes at shallow, upper crustal levels. This mush-rich zone could act as an impediment to eruptions until the mass and vigor of a recharge event, or a group of multiple closely spaced events, is able to remobilize enough of the mush plug to allow a gas-rich mixture of recharge magma plus mush to open the conduit to the surface and then continue the eruption. In this scenario, the VEI of the initial activity would be directly proportional to the volume and thermomechanical state of the mush plus the amount of gas furnished by short-term recharge input. In this sense, the volatile contents of the melt inclusions that we have measured are decoupled from eruptive vigor in that most of them represent melts that were trapped at shallow depths, after significant degassing and crystallization of previous replenishment magmas, rather than the necessarily large magma aliquot needed to trigger a paroxysmal eruption. The dynamics of Violent Strombolian eruptions at Llaima are related to the high gas flux of recharge magmas, which is recorded by only a very small fraction of the melt inclusions that are erupted. The maximum value of $4.5 \mathrm{wt} \%$ water that we have measured in only one melt inclusion may or may not accurately record the maximum water content of recharge magmas. However, monitoring gas fluxes at the vent and/or around the volcano may actually be effective in predicting the size of an upcoming event during period of unrest.

The notion that the mush zone could be lying at a perched and 'vulnerable' state following an initial period of many small replenishment events is consistent with the onset of a violent but short phase of activity on January 1, 2008. This paroxysm was not accompanied by a large or temporally extended seismic crisis (Hugo Moreno, personal communication 2010). The first surface manifestation of activity in 
May, 2007 does, however, provide an indication of when the mush plug began to increase in melt fraction and it marks the beginning of another seven months of time for the system to reach a state wherein mush bodies could be extensively remobilized. This interpretation is supported by an InSAR study of Volcán Llaima that identified a period of uplift from May, 2007 to November, 2008, following a subsidence period started in November, 2003 (Bathke et al., 2011). Through inverse modeling of both periods, a deflating and inflating magma body was inferred, located at a depth of 4-12 km, which is in agreement with the injection of a recharge magma just at the base of the mush inferred from this study $(\leq 4 \mathrm{~km}$ below the base of the edifice). In addition, Bathke et al. (2011) estimated an inflation rate $\sim 3$ times faster than the deflation rate, meaning a magma supply to the reservoir which is much faster than magma withdrawal, which is also in agreement with the high, long-term magma recharge flux suggested in this study.

More detailed geophysical studies aimed at identifying the number and depths of magma reservoirs beneath Volcán Llaima are essential to verify the proposed storage system. Melt inclusions only contain information from the time of entrapment onwards; i.e. once the magma has started crystallizing. Saito et al. (2010) studied the plumbing system of Miyakejima volcano (Japan) prior to the 2000 eruption. Geophysical studies reveal the presence of both deep and shallow magma reservoirs, whereas the volatile contents of both olivine- and plagioclase-hosted melt inclusions exclusively record entrapment at the depth of the shallow reservoir. It is the combination of both types of studies (geophysical and petrological) that permitted identification of the timing and location of magma mixing prior to the 2000 eruption. The compositions of the Miyakejima melt inclusions are similar to those from Llaima in many respects, and both systems are highly active and dominantly mafic, but the interpretation of magma evolution and ascent for Miyakejima (Saito et al., 2010) differs in many details from that which we infer for Llaima. We do not find it surprising that magmatic systems that are characterized by the eruption of evolved mafic magmas are dominantly recording an overprint by shallow processes.

\subsection{What can we say about individual eruptions?}


The 2008 eruption is probably the most representative of Llaima's eruptive behavior. It was erupted from the summit vent, and was of small to moderate volume, like most of Llaima eruptions documented in the historical record (Naranjo and Moreno, 2005). The tephra deposits of such eruptions are generally poorly preserved due to their limited thickness and restricted lateral extents, which is why we have studied only one of these common eruptions. After two years of activity, the amount of erupted magma during the 2008-2009 eruption is a small fraction of the 1955-1957 eruptive volume, and is also substantially less than the Fissural 3 ( 1850 AD) eruption and the other large historic events. This is the only historic eruption, which has been sampled in detail during eruption on the basis of temporal control (25 wholerock samples). The tephra erupted on January 1, 2008 ( 51.3-51.7 wt\% $\mathrm{SiO}_{2} ; 1.01-1.05 \mathrm{wt} \% \mathrm{TiO}_{2} ;$ Fig. 2 in supplementary material) and the February, 2008 lava $\left(\sim 52.0-52.1 \mathrm{wt} \% \mathrm{SiO}_{2} ; 1.11-1.13 \mathrm{wt} \% \mathrm{TiO}_{2}\right)$ are two distinct but apparently internally homogeneous magma batches. The 2009 lava is intermediate in composition between these two ( $\left.51.7-52.0 \mathrm{wt} \% \mathrm{SiO}_{2} ; 1.05-1.06 \mathrm{wt} \% \mathrm{TiO}_{2}\right)$. Melt inclusions record shallow magma storage as crystal mush, in a context of anastamosing dikes, as discussed above.

The 1955-57 eruption of Llaima is the most voluminous of the six large historic eruptions. Analyses of 22 lava samples from three lava flows on different sectors of the cone define a relatively narrow range of compositions ( $\left.~ 51.7-52.5 \mathrm{wt} \% \mathrm{SiO}_{2} ; 0.99-1.05 \mathrm{wt} \% \mathrm{TiO}_{2}\right) . \mathrm{H}_{2} \mathrm{O}-\mathrm{CO}_{2}$ data from 1957 melt inclusions are the only set of analyses that appear to approximate evolution along a closed-system degassing trend. This may reflect the relative importance of combined ascent (decompression) and degassing of magma prior to eruption. A potential correlation between $\mathrm{H}_{2} \mathrm{O}-\mathrm{CO}_{2}$-saturation pressures and a fractionation index such as $\mathrm{K}_{2} \mathrm{O}$ for the same unit (Fig. 9), suggests that the magma evolved by essentially plagioclase crystallization while ascending and degassing. The data from the 1957 tephra span a narrow range in temperature on an $\mathrm{H}_{2} \mathrm{O}$-free melt basis $\left(1110-1150^{\circ} \mathrm{C}\right.$; Fig. 8), with similar values for both melt inclusions $\left(1110-1140^{\circ} \mathrm{C}\right)$ and matrix glass $\left(1120-1150^{\circ} \mathrm{C}\right)$. All of these observations tend to suggest that the magma behaved primarily as a single coherent batch, evolving and degassing while ascending. A relatively limited participation of crystal mush bodies in an advanced state of solidification is consistent with the occurrence 
of significant lava-forming eruptions in 1945 and 1949, as it implies that this 10 year period was characterized by an unusually high rate of voluminous magma recharge/pulses. Olivines record a variety of core compositions, implying that many of them were entrained from multiple sources and incorporated into ascending magma. The large volume and relative compositional simplicity of this eruptive episode may signal that the fraction of recharge magma in the erupted products was unusually large for Llaima.

Closed melt inclusions from the lower Fissural 3 ( 1850 AD) unit are slightly more evolved and they record slightly cooler olivine-melt temperatures than glasses from the other units (Fig. 8). The lower Fissural 3 ( 1850 AD) magma may have experienced a slightly longer repose period before its extrusion, compared to the other magmas. This hypothesis is in agreement with lower ${ }^{226} \mathrm{Ra} /{ }^{230} \mathrm{Th}$, suggesting longer residence time or mingling with an older (few kyr) mush (Reubi et al., 2011). Mafic magma recharge events that trigger eruptions on the lower flanks of Llaima, such as the Fissural 3 ( 1850 AD) event, may encounter a more heterogeneous and partly more evolved family of mush bodies. This would be consistent with the relatively large range of compositions present in this eruption $\left(\sim 51.8-53.0 \mathrm{wt} . \% \mathrm{SiO}_{2}\right.$, and one at $54.3 ; 1.02-1.20 \mathrm{wt} . \% \mathrm{TiO}_{2}$ ). Flank lavas tend to be more heterogeneous at the level of single eruptions than are those erupted from the summit vents, due to lower long-term magma fluxes away from the main ascent route for magmas (Fig. 14).

Although subtle distinctions between individual eruptions are observed, general trends dominate. Crystallinities, whole-rock and melt inclusion compositions, and volatile contents are very similar for the four studied units. Olivine rims converge toward the same Fo content $\left(\mathrm{Fo}_{77-79}\right)$, and matrix temperatures are very similar $\left(\sim 1130^{\circ} \mathrm{C}\right)$. The volcano seems to be repeating itself from one eruption to the next and magmas are at similar conditions just prior to eruption. These observations are important for hazard assessment as they make Volcán Llaima a potentially predictable volcano.

\section{Conclusions}


Volcán Llaima has produced fundamentally similar magmas in terms of whole-rock compositions (evolved basalt to basaltic andesite), mineralogy (plagioclase, olivine, and minor clinopyroxene), and crystallinity (30-55 vol\% crystals) during the growth of the late Holocene edifice. The melt inclusions analyzed in this study are in part within the same range of compositions as whole-rock samples from the entire late Holocene edifice and they are similar from one eruption to the next. Matrix glass compositions, Fo-contents of olivine rims, and calculated olivine-melt temperatures are almost identical for all four studied eruptions. The volcano appears to have been operating in a repeatable state and erupting on short time scales for at least 1000 years. If Llaima is locked into a highly repetitive eruptive mode, including the processes that operate in its sub-volcanic plumbing-system, it offers volcanologists the opportunity to render it a predictable volcano when seismic monitoring results are integrated with these and subsequent petrologic insights.

Characterization of a large number of olivine-hosted melt inclusions from four historical tephra units at Volcán Llaima (2008 and 1957 summit eruptions, Fissural 3 ( 1850 AD) eruption) reveals that magmas are stored at very shallow depths (dominantly $\leq 4 \mathrm{~km}, 40-70 \mathrm{MPa}$ ), and that they undergo intense degassing and crystallization. Llaima magmas are most probably stored as many individual batches of crystal mush, perhaps in anastamosing dikes. This type of magma storage and solidification is probably common at many dominantly mafic arc volcanoes, but Llaima may be unusual in its capacity to maintain crystal mush bodies in a perched thermal state so that they retain sufficient melt fractions to render them frequently susceptible to remobilization and recycling in subsequently erupted magmas. We offer this working hypothesis as a potential framework for evaluating the eruptive mechanisms (through numerical modeling for example, in progress) and eventually understanding the shifts in eruptive styles at Llaima.

\section{Acknowledgements}

This project was supported by the Swiss NSF grant \#20_125019 to Dungan. We thank Jose-Antonio Naranjo, Hugo Moreno, Daniel Selles and the SENAGEOMIN for their help in the field and for providing 
access to the volcano during the period of eruptive activity in 2008. We thank Richard Hervig and Linda Williams for providing access to the SIMS laboratory and for their help during analysis, as well as Alexey Ulianov for providing access to the LA-ICP-MS laboratory and for his help running the instrument. We would also like to thank O. Reubi and L. Cooper for their useful advices and the fruitful scientific conversations we have had, as well as Tom Sisson and Genji Saito for their constructive reviews. 


\section{References}

Arth, J.G., 1976. Behavior of Trace-Elements during Magmatic Processes - Summary of Theoretical Models and Their Applications. Journal of Research of the US Geological Survey, 4(1): 41-47.

Bathke, H., Shirzaei, M. and Walter, T.R., 2011. Inflation and deflation at the steep-sided Llaima stratovolcano (Chile) detected by using InSAR. Geophysical Research Letters, 38: L10304, doi:10.1029/2011GL047168.

Beattie, P., 1993. Olivine-Melt and Ortho-Pyroxene-Melt Equilibria. Contributions to Mineralogy and Petrology, 115(1): 103-111.

Beattie, P., 1994. Systematics and Energetics of Trace-Element Partitioning between Olivine and Silicate Melts - Implications for the Nature of Mineral Melt Partitioning. Chemical Geology, 117(1-4): 5771.

Bindeman, I.N., Davis, A.M. and Drake, M.J., 1998. Ion microprobe study of plagioclase-basalt partition experiments at natural concentration levels of trace elements. Geochimica et Cosmochimica Acta, 62(7): 1175-1193.

Costa, F., Dohmen, R. and Chakraborty, S., 2008. Time Scales of Magmatic Processes from Modeling the Zoning Patterns of Crystals. Minerals, Inclusions and Volcanic Processes, 69: 545-594.

Danyushevsky, L.V., Della-Pasqua, F.N. and Sokolov, S., 2000. Re-equilibration of melt inclusions trapped by magnesian olivine phenocrysts from subduction-related magmas: petrological implications. Contributions to Mineralogy and Petrology, 138(1): 68-83.

Danyushevsky, L.V., McNeill, A.W. and Sobolev, A.V., 2002a. Experimental and petrological studies of melt inclusions in phenocrysts from mantle-derived magmas: an overview of techniques, advantages and complications. Chemical Geology, 183(1-4): 5-24.

Danyushevsky, L.V., Sokolov, S. and Falloon, T.J., 2002b. Melt inclusions in olivine phenocrysts: Using diffusive re-equilibration to determine the cooling history of a crystal, with implications for the origin of olivine-phyric volcanic rocks. Journal of Petrology, 43(9): 1651-1671.

DePaolo, D.J., 1981. Trace-Element and Isotopic Effects of Combined Wallrock Assimilation and Fractional Crystallization. Earth and Planetary Science Letters, 53(2): 189-202.

Dungan, M.A., Wulff, A. and Thompson, R., 2001. Eruptive stratigraphy of the Tatara-San Pedro complex, 36 degrees S, southern volcanic zone, Chilean Andes: Reconstruction method and implications for magma evolution at long-lived arc volcanic centers. Journal of Petrology, 42(3): 555-626.

Dzierma, Y. and Wehrmann, H., 2010. Eruption time series statistically examined: Probabilities of future eruptions at Villarrica and Llaima Volcanoes, Southern Volcanic Zone, Chile. Journal of Volcanology and Geothermal Research, 193(1-2): 82-92.

Finn, C. and Williams, D.L., 1982. Gravity Evidence for a Shallow Intrusion under Medicine Lake Volcano, California. Geology, 10(10): 503-507.

Gaetani, G.A. and Watson, E.B., 2002. Modeling the major-element evolution of olivine-hosted melt inclusions. Chemical Geology, 183(1-4): 25-41.

Gaetani, G.A., O'Leary, J.A. and Shimizu, N., 2009. Mechanisms and timescales for reequilibration of water in olivine-hosted melt inclusions. Eos Trans. AGU, 90(52), Fall Meet. Suppl., Abstract \#V51E-1770.

Guillong, M., Meier, D.L., Allan, M.M., Heinrich, C.A. and Yardley, B.W.D., 2008. SILLS: A MATLAB-based program for the reduction of laser ablation ICP-MS data of homogeneous materials and inclusions. Mineralogical Association of Canada Short Course, 40: 328-333.

Hauri, E., 2002. SIMS analysis of volatiles in silicate glasses, 2: isotopes and abundances in Hawaiian melt inclusions. Chemical Geology, 183(1-4): 115-141.

Higuchi, H. and Nagasawa, H., 1969. Partition of Trace Elements between Rock-Forming Minerals and Host Volcanic Rocks. Earth and Planetary Science Letters, 7(3): 281-287. 
Huber, C., Bachmann, O. and Manga, M., 2009. Homogenization processes in silicic magma chambers by stirring and mushification (latent heat buffering). Earth and Planetary Science Letters, 283(1-4): $38-47$.

Kazahaya, K., Shinohara, H. and Saito, G., 1994. Excessive degassing of Izu-Oshima volcano: Magma convection in a conduit. Bulletin of Volcanology, 56(3): 207-216.

Kelley, K.A. and Cottrell, E., 2009. Water and the Oxidation State of Subduction Zone Magmas. Science, 325(5940): 605-607.

Kent, A.J.R., 2008. Melt Inclusions in Basaltic and Related Volcanic Rocks. Minerals, Inclusions and Volcanic Processes, 69: 273-331.

Koyaguchi, T. and Kaneko, K., 1999. A two-stage thermal evolution model of magmas in continental crust. Journal of Petrology, 40(2): 241-254.

LaTourrette, T., Wasserburg, G.J. and Fahey, A.J., 1996. Self diffusion of Mg, Ca, Ba, Nd, Yb, Ti, Zr, and $\mathrm{U}$ in haplobasaltic melt. Geochimica et Cosmochimica Acta, 60(8): 1329-1340.

Lu, F.Q., Anderson, A.T. and Davis, A.M., 1995. Diffusional Gradients at the Crystal/Melt Interface and Their Effect on the Composition of Melt Inclusions. Journal of Geology, 103(5): 591-597.

Lucassen, F., Trumbull, R., Franz, G., Creixell, C., Vásquez, P., Romer, R.L. and Figueroa, O., 2004. Distinguishing crustal recycling and juvenile additions at active continental margins: the Paleozoic to recent compositional evolution of the Chilean Pacific margin (36-41 $\left.{ }^{\circ} \mathrm{S}\right)$. Journal of South American Earth Sciences, 17(2): 103-119.

Marsh, B.D., 1981. On the crystallinity, probability of occurrence, and rheology of lava and magma. Contributions to Mineralogy and Petrology, 78(1): 85-98.

Medard, E. and Grove, T.L., 2008. The effect of $\mathrm{H} 2 \mathrm{O}$ on the olivine liquidus of basaltic melts: experiments and thermodynamic models. Contributions to Mineralogy and Petrology, 155(4): 417-432.

Metrich, N., Bertagnini, A., Landi, P. and Rosi, M., 2001. Crystallization driven by decompression and water loss at Stromboli volcano (Aeolian Islands, Italy). Journal of Petrology, 42(8): 1471-1490.

Metrich, N., Bertagnini, A. and Di Muro, A., 2010. Conditions of Magma Storage, Degassing and Ascent at Stromboli: New Insights into the Volcano Plumbing System with Inferences on the Eruptive Dynamics. Journal of Petrology, 51(3): 603-626.

Naranjo, J.A. and Moreno, H., 2005. Geología del volcán Llaima, Región de la Araucanía, Carta Geológica de Chile, Serie Geología Básica. Servicio Nacional de Geología y Minería, Santiago, pp. No. 88,33 p.

Pan, V., Holloway, J.R. and Hervig, R.L., 1991. The Pressure and Temperature-Dependence of CarbonDioxide Solubility in Tholeiitic Basalt Melts. Geochimica et Cosmochimica Acta, 55(6): 15871595.

Papale, P., Moretti, R. and Barbato, D., 2006. The compositional dependence of the saturation surface of $\mathrm{H} 2 \mathrm{O}+\mathrm{CO} 2$ fluids in silicate melts. Chemical Geology, 229(1-3): 78-95.

Pearce, N.J.G., Perkins, W.T., Westgate, J.A., Gorton, M.P., Jackson, S.E., Neal, C.R. and Chenery, S.P., 1997. A compilation of new and published major and trace element data for NIST SRM 610 and NIST SRM 612 glass reference materials. Geostandards Newsletter-the Journal of Geostandards and Geoanalysis, 21(1): 115-144.

Pedersen, A.K., 1979. Basaltic Glass with High-Temperature Equilibrated Immiscible Sulfide Bodies with Native Iron from Disko, Central West Greenland. Contributions to Mineralogy and Petrology, 69(4): 397-407.

Portnyagin, M., Almeev, R., Matveev, S. and Holtz, F., 2008. Experimental evidence for rapid water exchange between melt inclusions in olivine and host magma. Earth and Planetary Science Letters, 272(3-4): 541-552.

Putirka, K.D., 2008. Thermometers and barometers for volcanic systems. Reviews in Mineralogy and Geochemistry, 69(1): 61-120. 
Reubi, O., Bourdon, B., Dungan, M.A., Koornneef, J.M., Sellés, D., Langmuir, C.H. and Aciego, S., 2011. Assimilation of the plutonic roots of the Andean arc controls variations in U-series disequilibria at Volcan Llaima, Chile. Earth and Planetary Science Letters, 303(1-2): 37-47.

Rosi, M., Bertagnini, A. and Landi, P., 2000. Onset of the persistent activity at Stromboli Volcano (Italy). Bulletin of Volcanology, 62(4-5): 294-300.

Saito, G., Morishita, Y. and Shinohara, H., 2010. Magma plumbing system of the 2000 eruption of Miyakejima volcano, Japan, deduced from volatile and major component contents of olivinehosted melt inclusions. Journal of Geophysical Research-Solid Earth, 115: B11202, doi:10.1029/2010JB007433.

Sisson, T.W. and Layne, G.D., 1993. H2O in basalt and basaltic andesite glass inclusions from four subduction-related volcanoes. Earth and Planetary Science Letters, 117(3-4): 619-635.

Shinohara, H., 2008. Excess Degassing from Volcanoes and Its Role on Eruptive and Intrusive Activity. Reviews of Geophysics, 46(4): RG4005, doi:10.1029/2007RG000244.

Vigneresse, J.-L., Barbey, P. and Cuney, M., 1996. Rheological Transitions During Partial Melting and Crystallization with Application to Felsic Magma Segregation and Transfer. Journal of Petrology, 37(6): 1579-1600.

Wallace, P.J., 2005. Volatiles in subduction zone magmas: concentrations and fluxes based on melt inclusion and volcanic gas data. Journal of Volcanology and Geothermal Research, 140(1-3): 217240. 


\section{Tables}

\begin{tabular}{|c|c|c|c|c|c|c|c|c|c|c|c|c|c|c|}
\hline Sample No & Unit & Type & $\begin{array}{l}\mathrm{SiO}_{2} \\
\mathrm{wt} \%\end{array}$ & $\begin{array}{l}\mathrm{TiO}_{2} \\
\mathrm{wt} \%\end{array}$ & $\begin{array}{l}\mathrm{Al}_{2} \mathrm{O}_{3} \\
\mathrm{wt} \%\end{array}$ & $\begin{array}{l}\mathrm{FeO}^{*} \\
\mathrm{wt} \%\end{array}$ & $\begin{array}{l}\mathrm{MnO} \\
\mathrm{wt} \%\end{array}$ & $\begin{array}{l}\mathrm{MgO} \\
\mathrm{wt} \%\end{array}$ & $\begin{array}{l}\mathrm{CaO} \\
\mathrm{wt} \%\end{array}$ & $\begin{array}{l}\mathrm{Na}_{2} \mathrm{O} \\
\mathrm{wt} \%\end{array}$ & $\begin{array}{l}\mathrm{K}_{2} \mathrm{O} \\
\mathrm{wt} \%\end{array}$ & $\begin{array}{l}\mathrm{P}_{2} \mathrm{O}_{5} \\
\mathrm{wt} \%\end{array}$ & $\begin{array}{l}\mathrm{T} \\
{ }^{\circ} \mathrm{C}\end{array}$ & $\begin{array}{l}\text { T-cor } \\
{ }^{\circ} \mathrm{C}\end{array}$ \\
\hline 8LM-331A_A18 & 2008 & closed & 50.89 & 1.08 & 17.90 & 10.00 & 0.18 & 5.56 & 10.06 & 3.23 & 0.57 & 0.00 & 1145 & \\
\hline 8LM-331A_A23 & 2008 & closed & 55.40 & 1.35 & 14.46 & 10.04 & 0.19 & 4.83 & 9.32 & 3.40 & 0.85 & 0.00 & 1128 & \\
\hline 8LM-331A_D5 & 2008 & closed & 55.78 & 2.19 & 13.89 & 11.25 & 0.19 & 3.60 & 8.07 & 3.19 & 1.30 & 0.20 & 1095 & 1023 \\
\hline 8LM-331A_A33m & 2008 & matrix & 52.55 & 1.29 & 16.23 & 10.51 & 0.19 & 4.46 & 9.89 & 3.73 & 0.76 & 0.00 & 1114 & \\
\hline 8LM-331A_A3m & 2008 & matrix & 52.94 & 1.21 & 15.60 & 10.17 & 0.15 & 6.75 & 8.38 & 3.58 & 0.83 & 0.00 & 1198 & \\
\hline 8LM-331A_B14m & 2008 & matrix & 53.97 & 1.26 & 16.08 & 9.94 & 0.18 & 5.18 & 9.12 & 3.20 & 0.76 & 0.00 & 1139 & 1139 \\
\hline 8LM-331A_A23m & 2008 & open & 52.86 & 1.23 & 16.26 & 10.23 & 0.21 & 4.89 & 9.71 & 3.48 & 0.72 & 0.00 & 1128 & 1094 \\
\hline 8LM-331A_B20m & 2008 & open & 53.39 & 1.25 & 16.20 & 10.27 & 0.21 & 4.70 & 9.66 & 3.07 & 0.76 & 0.08 & 1118 & \\
\hline 8LM-331A_D11 & 2008 & open & 52.60 & 1.12 & 16.06 & 10.14 & 0.15 & 6.32 & 8.80 & 3.69 & 0.70 & 0.00 & 1183 & \\
\hline TGL9-14B_A4b & 1957 & closed & 51.31 & 1.16 & 18.14 & 8.81 & 0.13 & 5.38 & 10.64 & 3.31 & 0.50 & 0.16 & 1132 & \\
\hline TGL9-14B_A6 & 1957 & closed & 55.88 & 1.63 & 14.40 & 10.41 & 0.24 & 4.37 & 7.62 & 3.98 & 0.99 & 0.15 & 1133 & 1046 \\
\hline TGL9-14B_A6d & 1957 & closed & 57.32 & 1.28 & 13.59 & 10.55 & 0.21 & 4.45 & 7.91 & 3.28 & 0.98 & 0.00 & 1129 & \\
\hline TGL9-14B_A11m & 1957 & matrix & 53.84 & 1.33 & 16.03 & 9.93 & 0.17 & 5.23 & 9.10 & 3.27 & 0.84 & 0.00 & 1141 & 1138 \\
\hline TGL9-14B_A4m & 1957 & matrix & 53.23 & 1.32 & 16.26 & 10.19 & 0.18 & 4.83 & 9.72 & 2.97 & 0.83 & 0.08 & 1122 & \\
\hline B_A7m & 1957 & $\mathrm{~m}$ & 52 & 1.23 & 15.36 & 0 & 0.20 & 5.29 & 9.67 & 33 & 74 & 0.00 & 1152 & 1152 \\
\hline TGL9-14B_A8 & 1957 & open & 53.61 & 1.27 & 15.98 & 10.21 & 0.21 & 4.92 & 9.21 & 3.43 & 0.76 & 0.00 & 1133 & \\
\hline TGL9-14B_C1 & 1957 & open & 59.95 & 1.24 & 16.04 & 10.38 & 0.19 & 4.88 & 9.53 & 3.55 & 0.75 & 0.00 & 1131 & \\
\hline 8LM-338_A29b & UF3 & closed & 49.23 & 0.92 & 17.63 & 11.55 & 0.23 & 6.62 & 10.46 & 2.77 & 0.42 & 0.00 & 1173 & \\
\hline 8LM-338_B11 & UF3 & clo & 5 & 1.91 & 16.18 & 8.90 & 0.18 & 4.63 & 9.79 & 3.02 & 0.70 & 0.10 & 1110 & \\
\hline 8LM-338_D12 & UF3 & closed & 55.20 & 1.71 & 13.49 & 11.84 & 0.24 & 4.24 & 7.87 & 3.77 & 1.14 & 0.15 & 1129 & 1065 \\
\hline 8LM-338_B16m2 & UF3 & matrix & 52.95 & 1.45 & 15.33 & 11.05 & 0.20 & 4.82 & 9.18 & 3.85 & 0.80 & 0.09 & 1135 & 1133 \\
\hline 8LM-338_D15m & UF3 & matrix & 51.64 & 1.23 & 15.84 & 11.01 & 0.19 & 5.43 & 9.89 & 3.43 & 0.81 & 0.09 & 1149 & \\
\hline 8LM-338_B1 & UF3 & open & 52.11 & 1.30 & 15.98 & 10.33 & 0.19 & 5.42 & 9.63 & 4.02 & 0.63 & 0.00 & 1152 & \\
\hline 8LM-338_B20m2 & UF3 & open & 52.76 & 1.25 & 16.27 & 10.03 & 0.20 & 5.33 & 9.40 & 3.58 & 0.76 & 0.00 & 1147 & \\
\hline 8LM-338_D1 & UF3 & open & 54.10 & 1.26 & 16.11 & 10.06 & 0.18 & 4.91 & 9.04 & 3.11 & 0.79 & 0.00 & 1131 & 1049 \\
\hline 8LM-339_A27 & LF3 & closed & 51.52 & 1.77 & 13.38 & 14.35 & 0.23 & 5.06 & 9.01 & 3.34 & 0.52 & 0.09 & 1153 & \\
\hline 8LM-339_B2 & LF3 & closed & 54.57 & 1.83 & 13.83 & 9.56 & 0.19 & 4.28 & 8.05 & 3.32 & 1.12 & 0.10 & 1011 & 915 \\
\hline 8LM-339_C22b & LF3 & closed & 51.57 & 0.96 & 18.74 & 8.45 & 0.16 & 5.43 & 10.33 & 3.24 & 0.59 & 0.00 & 1135 & \\
\hline 8LM-339_A1m & LF3 & matrix & 54.85 & 1.31 & 15.39 & 9.84 & 0.19 & 5.07 & 8.62 & 3.43 & 1.05 & 0.00 & 1142 & \\
\hline 8LM-339_A43m2 & LF3 & matrix & 52.49 & 1.27 & 15.95 & 10.44 & 0.19 & 5.27 & 9.77 & 3.56 & 0.65 & 0.00 & 1142 & \\
\hline 8LM-339_B10m & LF3 & matrix & 56.69 & 1.36 & 15.43 & 9.92 & 0.21 & 3.48 & 8.03 & 3.29 & 1.21 & 0.00 & 1087 & 1047 \\
\hline 8LM-339_B17 & LF3 & open & 51.76 & 1.16 & 16.93 & 10.63 & 0.19 & 5.23 & 9.93 & 3.10 & 0.66 & 0.00 & 1136 & \\
\hline 8LM-339_B23 & LF3 & open & 57.03 & 1.32 & 15.54 & 9.50 & 0.17 & 3.34 & 7.97 & 3.55 & 1.21 & 0.00 & 1083 & 1004 \\
\hline 8LM-339_C22_1 & LF3 & open & 54.47 & 1.07 & 16.69 & 9.08 & 0.17 & 4.81 & 9.13 & 3.37 & 0.81 & 0.00 & 1126 & 1035 \\
\hline
\end{tabular}

Table 1: Selected representative glass compositions corrected for post-entrapment modification when necessary. Uncorrected data can be found in the supplementary material. The temperature, $T\left({ }^{\circ} \mathrm{C}\right)$, was 
obtained using the model of Beattie (1993) considering a pressure of $50 \mathrm{MPa}$. T-cor is the temperature adjusted considering the amount of $\mathrm{H}_{2} \mathrm{O}$ present in the glass, using the equation of Médard and Grove (2008). UF3 = Upper Fissural $3(\sim 1850)$ and LF3 = Lower Fissural $3(\sim 1850)$.

\begin{tabular}{|c|c|c|c|c|c|c|c|c|c|c|c|c|c|}
\hline Sample No & $\begin{array}{l}\mathrm{H}_{2} \mathrm{O} \\
\mathrm{wt} \%\end{array}$ & $\begin{array}{l}\sigma \sigma \\
\mathrm{wt} \%\end{array}$ & $\begin{array}{l}\mathrm{CO}_{2} \\
\mathrm{ppm}\end{array}$ & $\begin{array}{l}1 \sigma \\
\mathrm{ppm}\end{array}$ & $\begin{array}{l}\mathrm{Cl} \\
\mathrm{ppm}\end{array}$ & $\begin{array}{l}1 \sigma \\
\mathrm{ppm}\end{array}$ & $\begin{array}{l}\mathrm{S} \\
\mathrm{ppm}\end{array}$ & $\begin{array}{l}1 \sigma \\
\mathrm{ppm}\end{array}$ & $\begin{array}{l}\text { SatP } \\
\mathrm{MPa}\end{array}$ & $\begin{array}{l}\mathrm{Sr} \\
\mathrm{ppm}\end{array}$ & $\begin{array}{l}1 \sigma \\
\mathrm{ppm}\end{array}$ & $\begin{array}{l}\mathrm{Zr} \\
\mathrm{ppm}\end{array}$ & $\begin{array}{l}1 \sigma \\
\mathrm{ppm}\end{array}$ \\
\hline 8LM-331A_A18 & & & & & 522 & 111 & 993 & 104 & & 478 & 2 & 74 & 1 \\
\hline 8LM-331A_A23 & & & & & 472 & 106 & 438 & 90 & & & & & \\
\hline 8LM-331A_D5 & 2.06 & 0.009 & 26 & 9 & 451 & 108 & 176 & 89 & 42.0 & & & & \\
\hline 8LM-331A_A33m & & & & & 524 & 106 & 443 & 92 & & & & & \\
\hline 8LM-331A_A3m & & & & & 352 & 107 & 512 & 91 & & & & & \\
\hline 8LM-331A_B14m & 0 & 0.002 & 0 & 6 & 342 & 105 & 192 & 114 & 0.0 & & & & \\
\hline 8LM-331A_A23m & 0.88 & 0.006 & 295 & 14 & 440 & 107 & 537 & 93 & 66.2 & 444 & 2 & 81 & 1 \\
\hline 8LM-331A_B20m & & & & & 480 & 106 & 549 & 93 & & 440 & 3 & 81 & 1 \\
\hline 8LM-331A_D11 & & & & & 530 & 106 & 603 & 93 & & & & & \\
\hline TGL9-14B_A4b & & & & & 401 & 108 & 866 & 101 & & & & & \\
\hline TGL9-14B_A6 & 2.62 & 0.006 & 190 & 8 & 304 & 104 & 319 & 87 & 64.6 & 365 & 2 & 114 & 1 \\
\hline TGL9-14B_A6d & & & & & 359 & 104 & 583 & 96 & & & & & \\
\hline TGL9-14B_A11m & 0.08 & 0.004 & & & 401 & 106 & 0 & 0 & & & & & \\
\hline TGL9-14B_A4m & & & & & 402 & 109 & 477 & 88 & & 455 & 2 & 86 & 1 \\
\hline TGL9-14B_A7m & 0 & 0.003 & & & 234 & 133 & 0 & 0 & & 457 & 2 & 87 & 1 \\
\hline TGL9-14B_A8 & & & & & 502 & 106 & 525 & 89 & & 438 & 2 & 82 & 1 \\
\hline TGL9-14B_C1 & & & & & 814 & 117 & 660 & 100 & & 437 & 2 & 83 & 1 \\
\hline 8LM-338_A29b & & & & & 508 & 110 & 1146 & 108 & & 492 & 9 & 60 & 3 \\
\hline 8LM-338_B11 & & & & & 511 & 108 & 1008 & 106 & & & & & \\
\hline 8LM-338_D12 & 1.82 & 0.006 & 178 & 20 & 363 & 110 & 209 & 125 & 88.9 & & & & \\
\hline 8LM-338_B16m2 & 0.06 & 0.004 & 13 & 4 & 347 & 104 & 0 & 0 & 6.2 & & & & \\
\hline 8LM-338_D15m & & & & & 437 & 108 & 591 & 92 & & & & & \\
\hline 8LM-338_B1 & & & & & 428 & 104 & 484 & 91 & & 442 & 2 & 77 & 1 \\
\hline 8LM-338_B20m2 & & & & & 449 & 109 & 598 & 94 & & 456 & 2 & 86 & 1 \\
\hline 8LM-338_D1 & 2.43 & 0.008 & 57 & 5 & 359 & 109 & 638 & 93 & 56.2 & 428 & 3 & 85 & 1 \\
\hline 8LM-339_A27 & & & & & 739 & 117 & 1315 & 115 & & & & & \\
\hline 8LM-339_B2 & 3.05 & 0.009 & 96 & 9 & 642 & 108 & 420 & 89 & 79.8 & 370 & 2 & 128 & 1 \\
\hline 8LM-339_C22b & & & & & 565 & 111 & 1084 & 107 & & 515 & 1 & 55 & $<1$ \\
\hline 8LM-339_A1m & & & & & 357 & 106 & 0 & 0 & & & & & \\
\hline 8LM-339_A43m2 & & & & & 463 & 106 & 511 & 94 & & & & & \\
\hline 8LM-339_B10m & 1.09 & 0.005 & 41 & 4 & 652 & 112 & 400 & 88 & & 399 & 2 & 106 & 1 \\
\hline 8LM-339_B17 & & & & & 431 & 108 & 513 & 96 & & 430 & 2 & 69 & 1 \\
\hline 8LM-339_B23 & 2.31 & 0.013 & 98 & 11 & 720 & 110 & 322 & 89 & 62.7 & 413 & 2 & 108 & 1 \\
\hline 8LM-339_C22_1 & 2.79 & 0.009 & 2 & 3 & 507 & 111 & 574 & 93 & 58.0 & 463 & 1 & 70 & $<1$ \\
\hline
\end{tabular}

Table $\mathrm{I}$ (continued). SatP is the $\mathrm{H}_{2} \mathrm{O}-\mathrm{CO}_{2}$ saturation pressure obtained using the model of Papale et al. (2006) considering a temperature of $1130^{\circ} \mathrm{C}$. 


\begin{tabular}{lllllllllllllll}
\hline Unit & & $\mathrm{n}$ & $\mathrm{SiO}_{2}$ & $\mathrm{TiO}_{2}$ & $\mathrm{Al}_{2} \mathrm{O}_{3}$ & $\mathrm{FeO}^{*}$ & $\mathrm{MnO}$ & $\mathrm{MgO}$ & $\mathrm{CaO}$ & $\mathrm{Na}_{2} \mathrm{O}$ & $\mathrm{K}_{2} \mathrm{O}$ & $\mathrm{P}_{2} \mathrm{O}_{5}$ & $\mathrm{Sr}$ & $\mathrm{Zr}$ \\
\hline $\mathbf{2 0 0 8}$ & $\mathrm{Av}$. & 25 & 51.80 & 1.07 & 17.87 & 10.09 & 0.16 & 5.69 & 9.67 & 2.78 & 0.63 & 0.20 & 76 & 452 \\
$\mathbf{2 0 0 8}$ & StdDev & & 0.25 & 0.05 & 0.17 & 0.11 & 0.00 & 0.19 & 0.16 & 0.06 & 0.05 & 0.01 & 7 & 4 \\
$\mathbf{1 9 5 7}$ & Av. & 21 & 52.04 & 1.02 & 17.82 & 9.81 & 0.16 & 5.70 & 9.58 & 3.03 & 0.64 & 0.19 & 72 & 463 \\
$\mathbf{1 9 5 7}$ & StdDev & & 0.18 & 0.02 & 0.12 & 0.05 & 0.00 & 0.10 & 0.14 & 0.09 & 0.03 & 0.01 & 2 & 4 \\
$\mathbf{F 3}$ & Av. & 30 & 52.41 & 1.14 & 17.68 & 10.18 & 0.17 & 5.23 & 9.24 & 3.05 & 0.71 & 0.21 & 87 & 445 \\
$\mathbf{F 3}$ & StdDev & & 0.41 & 0.06 & 0.35 & 0.22 & 0.00 & 0.25 & 0.26 & 0.16 & 0.07 & 0.02 & 9 & 9 \\
\hline
\end{tabular}

Table 2: Average whole-rock compositions of lava and tephra. Sr and Zr contents are in ppm, the other concentrations are given in wt\%. F3 = Fissural 3 ( 1850), Av. is the average, StdDev is the standard deviation, and $n$ is the number of samples analyzed.

\begin{tabular}{lllllll}
\hline $\begin{array}{l}\text { Sample } \\
\text { No. }\end{array}$ & $\mathrm{P}-\mathrm{MPa}$ & $\mathrm{T}-{ }^{\circ} \mathrm{C}$ & $\begin{array}{l}\mathrm{H}_{2} \mathrm{O}(\mathrm{wt} \%) \\
\text { manometry }\end{array}$ & $\begin{array}{l}\mathrm{H}_{2} \mathrm{O}(\mathrm{wt} \%) \\
\mathrm{FTIR}\end{array}$ & $\begin{array}{l}\mathrm{CO}_{2}(\mathrm{ppm}) \\
\text { manometry }\end{array}$ & $\begin{array}{l}\mathrm{CO}_{2}(\mathrm{ppm}) \\
\text { FTIR }\end{array}$ \\
\hline $\mathbf{A - 3 4}$ & 410 & 1200 & $5.5(0.1)$ & 5.2 & $2655(195)$ & 2270 \\
$\mathbf{A - 3 6}$ & 740 & 1200 & $6.3(0.2)$ & 6.0 & $7050(230)$ & 6210 \\
$\mathbf{A - 5 1}$ & 410 & 1200 & $3.2(0.3)$ & 4.1 & $2545(470)$ & 2780 \\
$\mathbf{A - 6 8}$ & 620 & 1200 & $2.0(0.3)$ & 2.1 & $5150(420)$ & 5720 \\
$\mathbf{A - 7 2}$ & 420 & 1200 & $2.3(0.3)$ & 2.7 & $2410(380)$ & 2725 \\
$\mathbf{A 2 - 9 3}$ & 420 & 1200 & $1.6(0.3)$ & 1.8 & $6710(480)$ & 5240 \\
\hline
\end{tabular}

Table 3: Run conditions, manometry, and FTIR results for dissolved $\mathrm{H}_{2} \mathrm{O}$ and $\mathrm{CO}_{2}$ contents in the standards. FTIR data exclusively were used for the calibration curves. Samples were synthesized and characterized by Gordon Moore, Kurt Roggensack (ASU) and Torsten Vennemann (UNIL)

\begin{tabular}{llllllllll}
\hline & $\mathrm{SiO} 2$ & $\mathrm{TiO2}$ & $\mathrm{Al} 2 \mathrm{O3}$ & $\mathrm{FeO}^{*}$ & $\mathrm{MgO}$ & $\mathrm{CaO}$ & $\mathrm{Na} 20$ & $\mathrm{~K} 20$ & Total \\
\hline $\mathbf{A}$ & 49.30 & 0.97 & 15.50 & 10.40 & 8.30 & 12.55 & 2.40 & 0.26 & 99.68 \\
$\mathbf{A 2}$ & 45.80 & 0.90 & 14.10 & 9.62 & 7.80 & 18.54 & 2.00 & 0.26 & 99.02 \\
\hline
\end{tabular}

Basalt glass starting compositions for the standards, as determined by electron microprobe 


\begin{tabular}{|c|c|c|c|c|}
\hline Plot & 2008 & 1957 & UF3 & LF3 \\
\hline $\mathrm{H}_{2} \mathrm{O}$ vs $\mathrm{TiO}_{2}$ & 0.0123 & 0.0163 & 0.0003 & 0.0141 \\
\hline $\mathrm{H}_{2} \mathrm{O}$ vs $\mathrm{Al}_{2} \mathrm{O}_{3}$ & 0.0366 & 0.0254 & 0.0161 & 0.0179 \\
\hline $\mathrm{CO}_{2}$ vs $\mathrm{TiO}_{2}$ & 0.1118 & 0.0035 & 0.0001 & 0.0541 \\
\hline $\mathrm{CO}_{2} \mathrm{vs} \mathrm{Al}_{2} \mathrm{O}_{3}$ & 0.1414 & 0.0012 & $2.00 \mathrm{E}-05$ & 0.0668 \\
\hline $\mathrm{K}_{2} \mathrm{O}$ vs SatP & 0.1046 & 0.0684 & 0.0434 & 0.0334 \\
\hline $\mathrm{Al}_{2} \mathrm{O}_{3}$ vs SatP & 0.0054 & 0.0158 & 0.0744 & 0.0694 \\
\hline $\mathrm{H}_{2} \mathrm{O}$ vs S & 0.0481 & 0.2706 & 0.4389 & 0.2987 \\
\hline $\mathrm{H}_{2} \mathrm{O}$ vs Cl & $8.00 \mathrm{E}-07$ & 0.0145 & 0.3043 & 0.161 \\
\hline $\mathrm{CO}_{2}$ vs S & 0.403 & 0.289 & 0.2922 & 0.0204 \\
\hline $\mathrm{CO}_{2}$ vs $\mathrm{Cl}$ & 0.1779 & 0.0037 & 0.1818 & 0.0304 \\
\hline $\mathrm{H}_{2} \mathrm{O}$ vs $\mathrm{S} / \mathrm{Cl}$ & 0.0664 & 0.5339 & 0.4009 & 0.2283 \\
\hline $\mathrm{CO}_{2}$ vs S/Cl & 0.3014 & 0.3959 & 0.2836 & 0.0594 \\
\hline $\mathrm{S}$ vs $\mathrm{Cl}$ & 0.4363 & 0.3134 & 0.3196 & 0.2913 \\
\hline $\mathrm{S} / \mathrm{K}_{2} \mathrm{O}$ vs $\mathrm{Cl} / \mathrm{K}_{2} \mathrm{O}$ & 0.6795 & 0.5739 & 0.7592 & 0.7431 \\
\hline $\mathrm{K}_{2} \mathrm{O}$ vs $\mathrm{S} / \mathrm{Cl}$ & 0.4243 & 0.2186 & 0.234 & 0.0766 \\
\hline
\end{tabular}

Table 4: Coefficients of determination obtained from linear regressions to evaluate the degree of correlation between volatiles and major elements and between different volatile species. SatP is the $\mathrm{H}_{2} \mathrm{O}$ $\mathrm{CO}_{2}$ saturation pressure obtained using the model of Papale et al. (2006) considering a temperature of $1130^{\circ} \mathrm{C}$, UF3 $=$ Upper Fissural $3(\sim 1850)$, and LF3 = Lower Fissural $3(\sim 1850)$.

\begin{tabular}{ccccc}
\hline & Olivine & Ref. & Plagioclase & Ref. \\
\hline $\mathbf{D}^{\mathbf{T i}}$ & 0.08 & (Pedersen, 1979) & 0.197 & (Bindeman et al., 1998) \\
$\mathbf{D}^{\mathbf{A l}}$ & 0.015 & (Beattie, 1994) & 1.63 & (Higuchi and Nagasawa, 1969) \\
$\mathbf{D}^{\mathbf{S r}}$ & 0.014 & (Arth, 1976) & 1.83 & (Arth, 1976) \\
$\mathbf{D}^{\mathbf{Z r}}$ & 0.012 & (Arth, 1976) & 0.048 & (Arth, 1976) \\
Proportion & 0.1 & & 0.9 & \\
\hline
\end{tabular}

Table 5: Distribution coefficients and phase proportions used for Rayleigh fractionation and assimilationfractional crystallization modeling (AFC-DePaolo, 1981).

\begin{tabular}{cccccccccc}
\hline $\mathrm{SiO} 2$ & $\mathrm{TiO} 2$ & $\mathrm{Al} 2 \mathrm{O} 3$ & $\mathrm{FeO}^{*}$ & $\mathrm{MgO}$ & $\mathrm{CaO}$ & $\mathrm{Na} 20$ & $\mathrm{~K} 20$ & $\mathrm{Sr}$ & $\mathrm{Zr}$ \\
\hline 69.7 & 0.5 & 14.9 & 2.7 & 0.86 & 2.14 & 4.11 & 4.2 & 213.1 & 18.71 \\
\hline
\end{tabular}

Composition of the assimilated granite (T-00-56; Lucassen et al. 2004). All concentrations are in wt\% except for $\mathrm{Sr}$ and $\mathrm{Zr}$ which are in ppm. 


\section{Figure Captions}

Figure 1: Geological map of Volcán Llaima modified after (Naranjo and Moreno, 2005) and focused on the Holocene cone. Historic lava flows are labeled and pre-historic lava flows are undifferentiated and marked with oblique stripes. Notice the presence of ice around the summit vent (white patch around the big star). This study focuses on 4 tephra units of the Holocene cone, belonging to the 2008, 1957 and Fissural 3 ( 1850) eruptions. Samples were taken from two stratigraphic sections, marked by small stars on the map and located close to the Fissural $3(\sim 1850)$ vents and next to the southern lobe of the Fissural $3(\sim 1850)$ lava flow. The inlet in the lower left corner is a simplified map of the southern part of the Southern Volcanic Zone of the Andes. Volcán Llaima is located about $700 \mathrm{~km}$ south of Santiago de Chile, in the Longavi-Osorno segment as defined by (Dungan et al., 2001).

Figure 2: Top: Mode composition obtained by point-counting on scanned thin sections. The phenocrysts are plagioclase, olivine and minor pyroxene. Lava flows can contain up to 64 vol\% phenocrysts, and are generally more crystalline than tephra (up to 30 vol\% phenocrysts). Bottom: Scanned thin sections of a highly crystalline lava flow on the left, and of a less crystalline scoria to the right. Tephra samples were impregnated in blue epoxy in order to better visualize the vesicles.

Figure 3: (a) Typical olivine displaying the three types of glasses analyzed, i.e. closed melt inclusions, open melt inclusions (embayments), and matrix glass. (b) Some olivines display very large melt channels between and inside grains. (c) Melt inclusion containing an idiomorphic plagioclase crystal which was incorporated during the growth of the host olivine in a highly crystalline environment. (d) Two merged olivine crystals reflecting high crystallinities in the magma storage area. (e) Natural light and (f) reflected light image of a high melt inclusion density olivine. Typical (g) rounded, (h) wormy, and (i) inverse crystal shape melt inclusions. Note that all are glassy. Typical long and wormy (j) or short and rounded (k) olivine embayments. (l) Example of matrix glass containing very minor plagioclase microlites. 
Figure 4: Mg\# of the analyzed glasses considering an oxygen fugacity of NNO (colored symbols) and of QFM (gray shaded area) versus Fo content of the host olivine adjacent to the analyzed glass. Full and dashed lines correspond to olivine-liquid equilibrium for an Fe-Mg exchange coefficient $\mathrm{k}_{\mathrm{D}}$ of $0.3 \pm 0.03$ (Putirka, 2008). Data considering an oxygen fugacity of QFM plots at slightly lower Mg\# than the data considering an oxygen fugacity of NNO. In this study we assumed an oxygen fugacity of NNO and melt inclusion compositions were corrected considering that they were shifted out of equilibrium due to post-entrapment crystallization (PEC; shifted to the left of the equilibrium curves) or post-entrapment melting (PEM; shifted to the right of the equilibrium curves).

Figure 5: $\mathrm{MgO}$ versus total $\mathrm{Fe}(\mathrm{FeO} *)$ contents of glass (colored symbols), whole-rocks from the three studied eruptions (2008, 1957, and Fissural 3, marked with black symbols), and whole-rocks from the entire volcano (gray shaded area). Lines in the background show equilibrium olivine composition. Glass compositions are in equilibrium with more evolved olivine compositions than their associated whole-rocks, reflecting intense magma crystallization and the differentiation of interstitial melt. Closed melt inclusions are marked with closed symbols, open inclusions (embayments) are marked with open symbols, and matrix glasses are marked with crosses. Closed melt inclusions tend to be in equilibrium with more evolved olivine compositions (down to $\mathrm{Fo}_{71}$ ) than open melt inclusions and matrix glass (between $\mathrm{Fo}_{77}$ and $\mathrm{Fo}_{83}$ ) or whole-rocks from the same unit (up to $\mathrm{Fo}_{83}$ ), implying a mafic magma recharge.

Figure 6: (a) Olivine zoning profiles (4-6 points) for the 2008, 1957, Upper Fissural 3 (UF3), and Lower Fissural 3 (LF3) units. Dashed lines highlight normally zoned crystals whereas full lines correspond to reversely zoned crystals. Core compositions are extremely diverse; however rim compositions tend to focus around the same Fo values for all four units. (b) Histogram of rim Fo contents for the four tephra units studied. Rim compositions cluster around $\mathrm{Fo}_{78-80}$ in all units.

Figure 7: Major element variation plots comparing melt inclusion and matrix glass trends (colored symbols in the plots to the left) with the whole-rock compositions of the eruptions studied (black symbols in the plots to the right) and the whole-rock trends of the entire suite of magmas erupted at 
Llaima (gray shaded area in the plots to the left and to the right). Closed melt inclusions are marked with closed symbols, open inclusions (embayments) are marked with open symbols, and matrix glasses are marked with crosses. Glass compositions overlap with whole-rock compositions and closed melt inclusions prolong the whole-rock trend toward lower $\mathrm{Al}_{2} \mathrm{O}_{3}$ and higher $\mathrm{TiO}_{2}$ contents, indicating intense plagioclase crystallization and the suppression of FeTi-oxide stability.

Figure 8: Temperature versus Mg number (Mg\#) for the 2008, 1957, Upper Fissural 3 (UF3), and Lower Fissural 3 (LF3) units. Temperatures were obtained from olivine-liquid equilibrium using the model of Beattie (1993), the error is of $\pm 30^{\circ} \mathrm{C}$. When corrected for the presence of dissolved $\mathrm{H}_{2} \mathrm{O}$ in the melt using the expression of Médard and Grove (2008), closed and open melt inclusion temperatures are lowered by $60-110^{\circ} \mathrm{C}$. Matrix glass temperatures (black crosses) stay unchanged and plot at the higher $\mathrm{Mg \#}$, higher temperature end of the trend. Similar matrix temperatures (around $1130-1150^{\circ} \mathrm{C}$ ) are observed for all four units.

Figure 9: $\mathrm{H}_{2} \mathrm{O}$ versus $\mathrm{CO}_{2}$ plots for the 2008, 1957, Upper Fissural 3 (UF3), and Lower Fissural 3 (LF3) units. Error bars are generally smaller than symbol size, and the few that are not are never larger than $20 \%$ of the symbol size. Gray curves are isobars in MPa obtained using the model of Papale et al. (2006), considering the average composition of the 2008 glasses (data reported in Table 1 of the supplementary material; $\left.53.98 \mathrm{wt} \% \mathrm{SiO}_{2}, 2.23 \mathrm{wt} \% \mathrm{Fe}_{2} \mathrm{O}_{3}, 8.37 \mathrm{wt} \% \mathrm{FeO}\right)$. Considering the average composition of each individual unit does not change the position of the isobars significantly. Matrix glass (crosses) is extensively degassed. Only data for the 1957 unit seem to define a degassing trend, data for the other units define clouds around $50 \mathrm{MPa}$ indicative of shallow magma storage.

Figure 10: $\mathrm{H}_{2} \mathrm{O}-\mathrm{CO}_{2}$-saturation pressures obtained using the model of Papale et al. (2006) versus $\mathrm{K}_{2} \mathrm{O}$, a fractionation index, for the 2008, 1957, Upper Fissural 3 (UF3), and Lower Fissural 3 (LF3) units. No simultaneous degassing and evolution trends are visible, except maybe for a slight correlation in the 1957 data, suggesting that in general magmas at Llaima are simply stalled and evolving at shallow depths. The 1957 magma however may have been ascending (decompressing) while it was evolving. 
Figure 11: $\mathrm{H}_{2} \mathrm{O}$ (left) and $\mathrm{CO}_{2}$ (right) versus $\mathrm{K}_{2} \mathrm{O}$ plots showing no correlation between major elements and volatiles. Coefficients of determination obtained from linear regressions were estimated for $\mathrm{K}_{2} \mathrm{O}$ and other major elements, and they all yield values lower than 0.2 for all four units (Table 4 ). We thereby infer that magmas were stored in several batches, experiencing multiple degassing and crystallization paths.

Figure 12: (a) Chlorine versus Sulfur plot showing a mild positive correlation. Average errors for $\mathrm{S}$ and $\mathrm{Cl}$ are $\pm 90 \mathrm{ppm}$ and $\pm 110 \mathrm{ppm}$ respectively. (b) $\mathrm{Cl} / \mathrm{K}_{2} \mathrm{O}$ versus $\mathrm{S} / \mathrm{K}_{2} \mathrm{O}$ plot showing a stronger positive correlation once these volatile species are normalized to a fractionation index, and (c) $\mathrm{K}_{2} \mathrm{O}$ versus $\mathrm{S} / \mathrm{Cl}$ plot showing a broad negative correlation suggesting that $\mathrm{S}$ degasses as the magma evolves. Coefficients of determination obtained from linear regressions for these three plots can be found in Table 4.

Figure 13: $\mathrm{Sr} / \mathrm{Zr}$ vesus $\mathrm{Al}_{2} \mathrm{O}_{3}$ (left) and $\mathrm{TiO}_{2}$ (right) showing clear positive and negative correlations respectively. Closed melt inclusions are marked with closed symbols, open inclusions (embayments) are marked with open symbols, and matrix glasses are marked with crosses. Closed melt inclusions define the trend from high $\mathrm{Sr} / \mathrm{Zr}$ down to low $\mathrm{Sr} / \mathrm{Zr}$. Open inclusions and matrix glass span a similar range in $\mathrm{Sr} / \mathrm{Zr}$, narrower than the closed melt inclusion range and centered on the trend. They are interpreted as diffusive mixing and homogenization of a high $\mathrm{Sr} / \mathrm{Zr}$ recharge magma with a low $\mathrm{Sr} / \mathrm{Zr}$ evolved interstitial liquid. Associated whole-rocks (gray shaded area) have intermediate $\mathrm{Sr} / \mathrm{Zr}$ values similar to the open inclusions and matrix glass (due to averaging over the sample), but higher $\mathrm{Al}_{2} \mathrm{O}_{3}$ and lower $\mathrm{TiO}_{2}$ contents than glasses with the same $\mathrm{Sr} / \mathrm{Zr}$ due to their high plagioclase contents and the absence of FeTi-oxides. The black curves are Rayleigh fractionation (FC) and assimilation-fractional crystallization (AFC) models showing that the $\mathrm{Sr} / \mathrm{Zr}$ vs $\mathrm{Al}_{2} \mathrm{O}_{3}$ and $\mathrm{TiO}_{2}$ trends can be explained by variable degrees of crystallization from the least evolved composition. Assimilation does not seem to affect $\mathrm{Sr} / \mathrm{Zr}$ ratios; both FC and AFC models imply up to $~ 55$ wt\% (i.e. $\sim 54 \mathrm{vol} \%$ ) crystallization. Model parameters are reported in Table 5. 
Figure 14: Schematic view of the dike complex acting as a reservoir for Llaima magmas. This geometry would account for the observed diversity in olivine core compositions, the absence in correlation between degassing and magma fractionation trends, and is in agreement with the faultcontrolled distribution of vents. We believe that individual dikes are about 3-4 km deep, $\sim 5 \mathrm{~km}$ long and a few tens of meters wide. Magma extrusion from multiple dikes would account for the erupted magma volumes observed.

\section{Supplementary Material}

Figure 1: Melt inclusion diameter versus $\mathrm{Mg \# ,} \mathrm{FeO}$ and $\mathrm{MgO}$ content of the melt. No trend can be defined for any of the four tephra units studied implying that boundary layer melt entrapment during melt inclusion formation did not affect the composition of the melt inclusions.

Figure 2: Comparison of 2008 tephra, 2008 and 2009 lava whole-rock compositions. The tephra erupted on January 1, 2008 and the February, 2008 lava are two distinct but apparently internally homogeneous magma batches. The 2009 lava is intermediate in composition between these two.

Table 1: Major element, volatile, and trace element composition of all the melt inclusions analyzed. The file contains four spreadsheets, one per tephra unit studied (2008, 1957, UF3, LF3). 


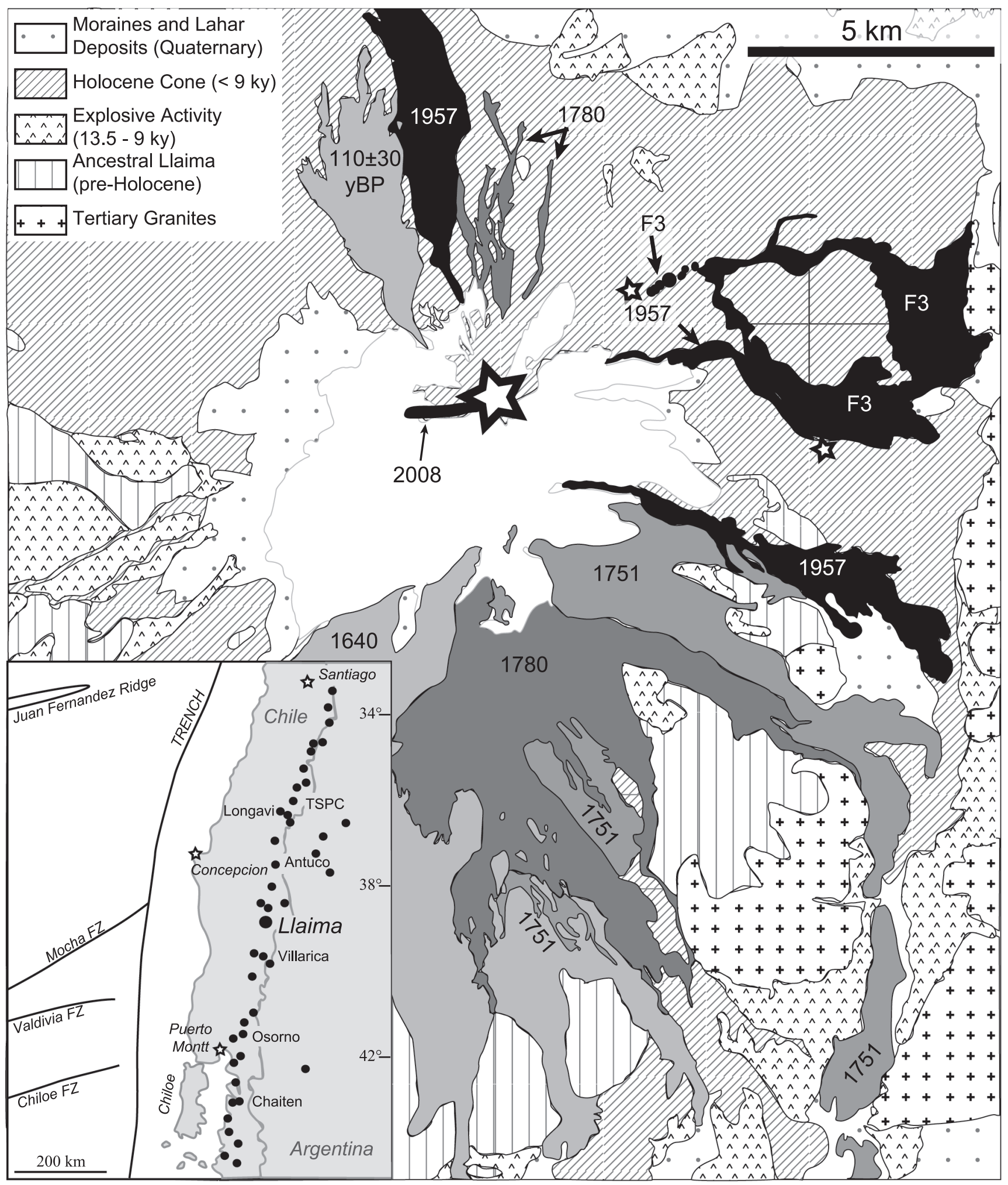

\section{Figure 1:}



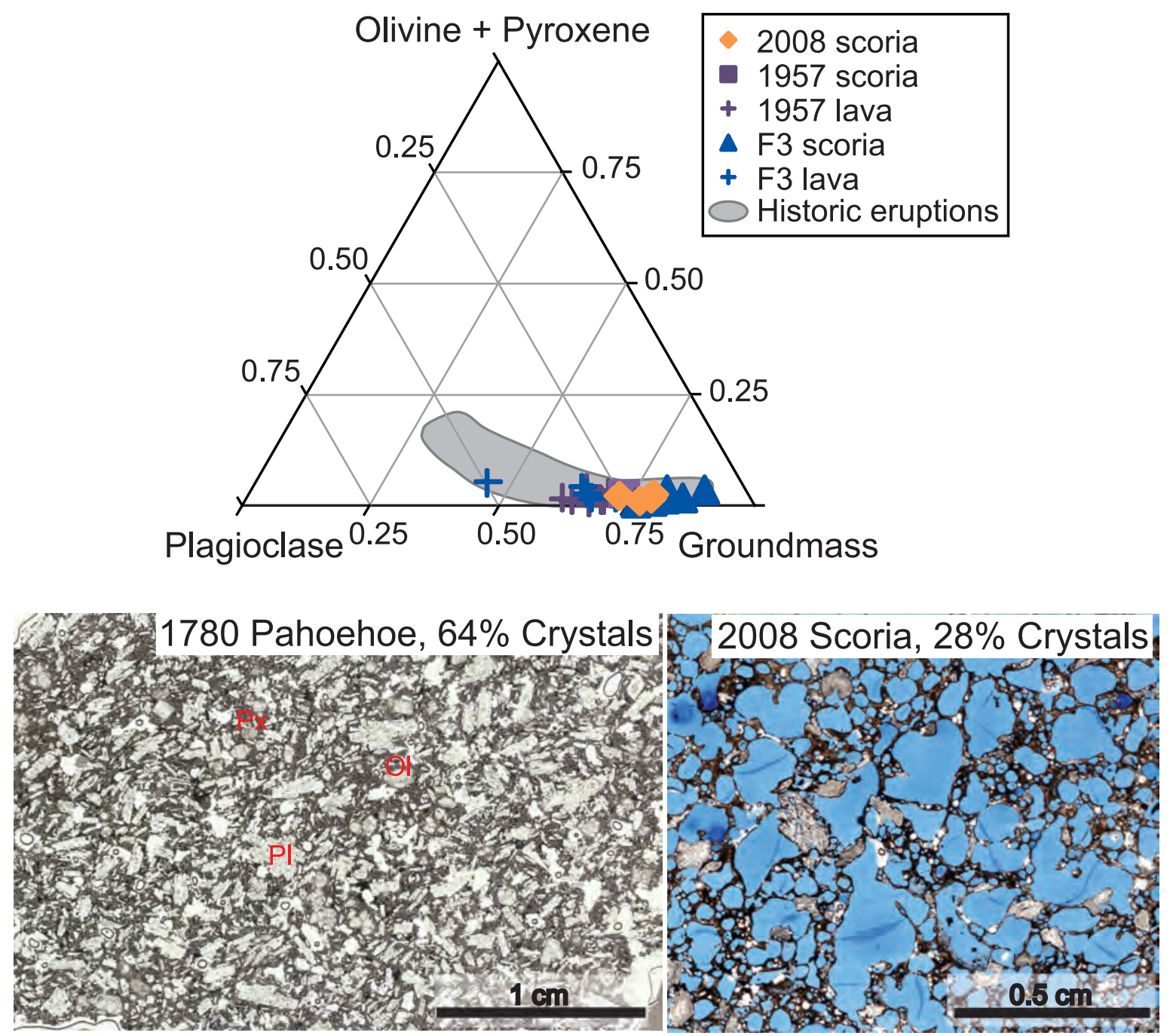

Figure 2 

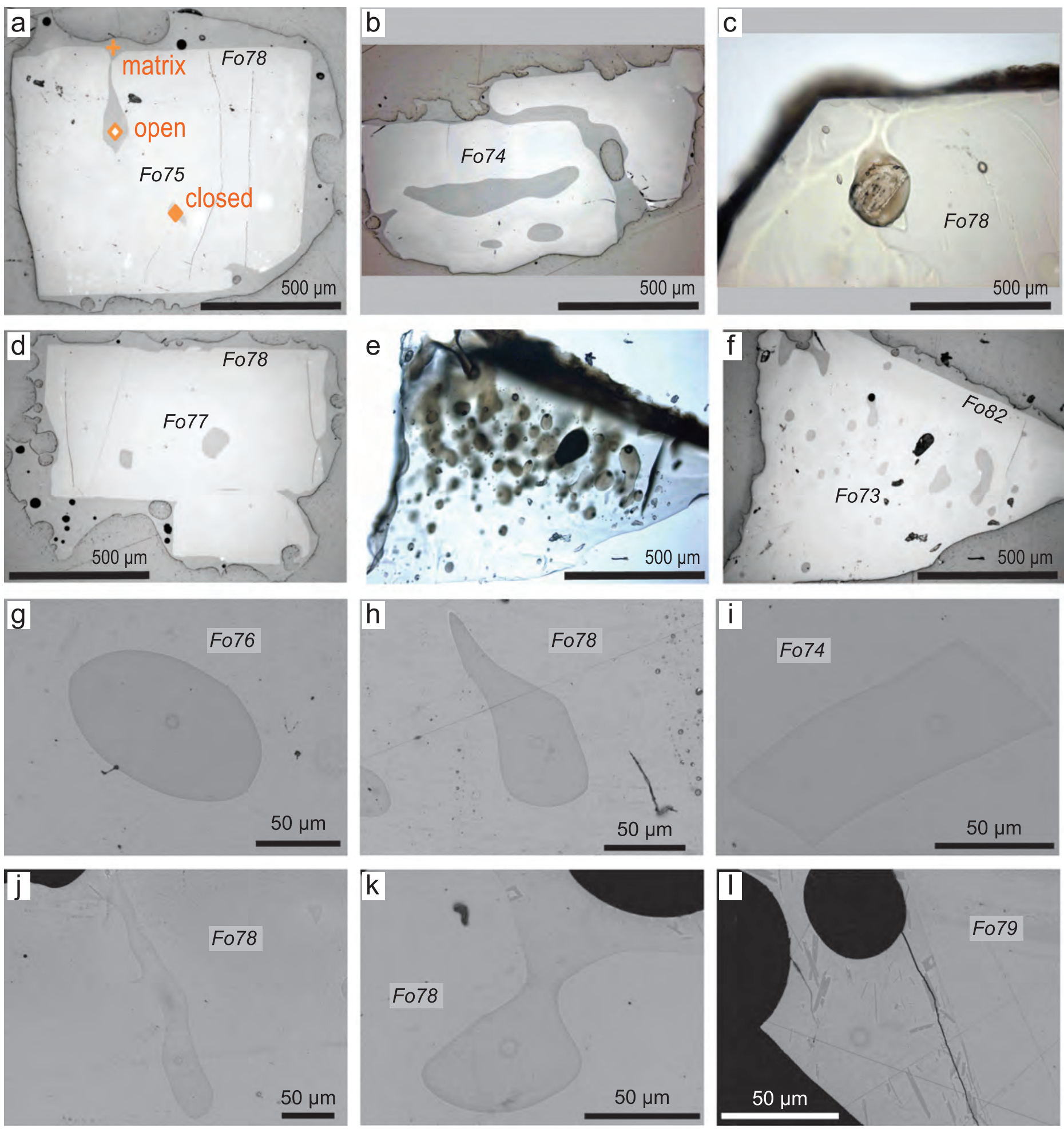

Figure 3 


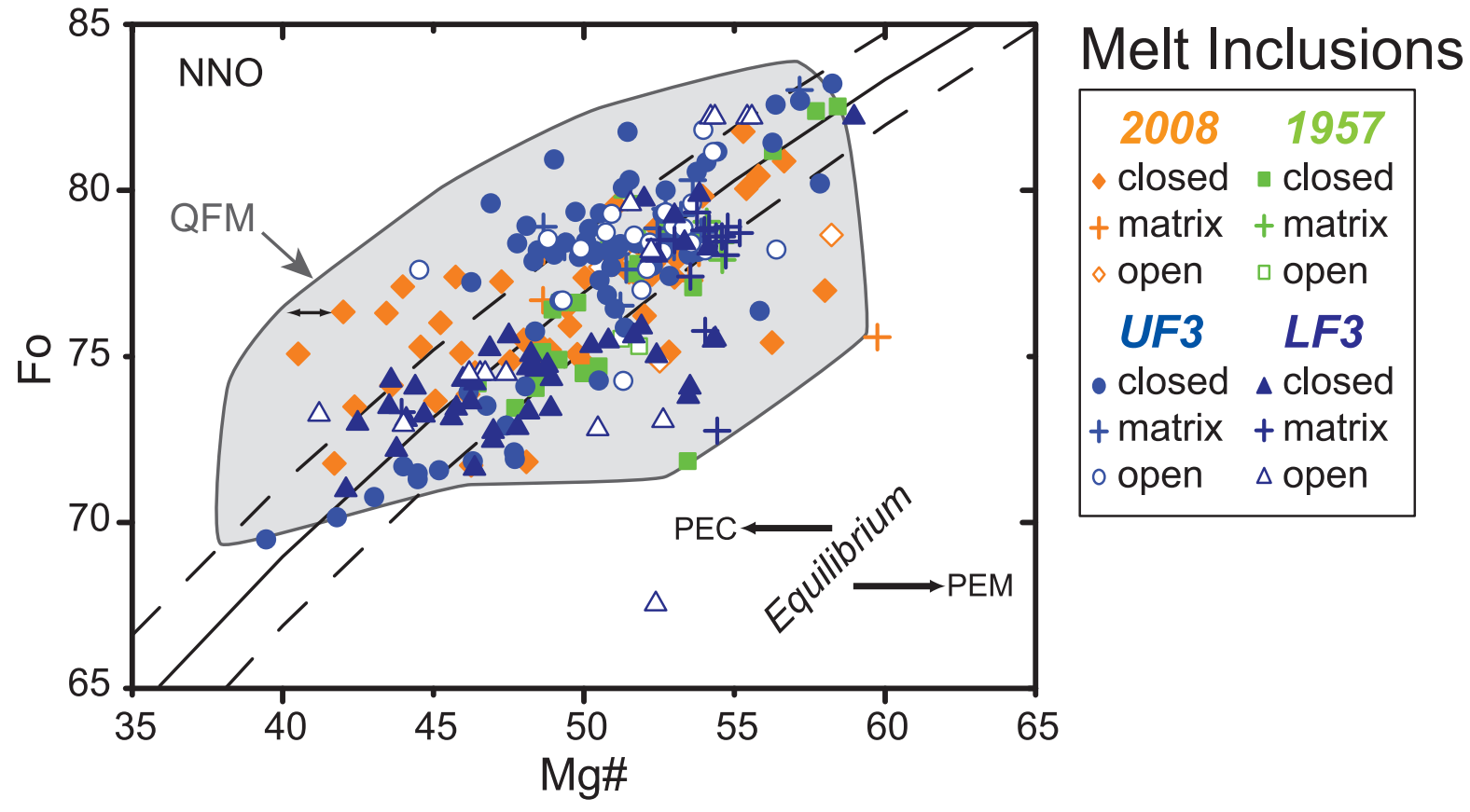

Figure 4 


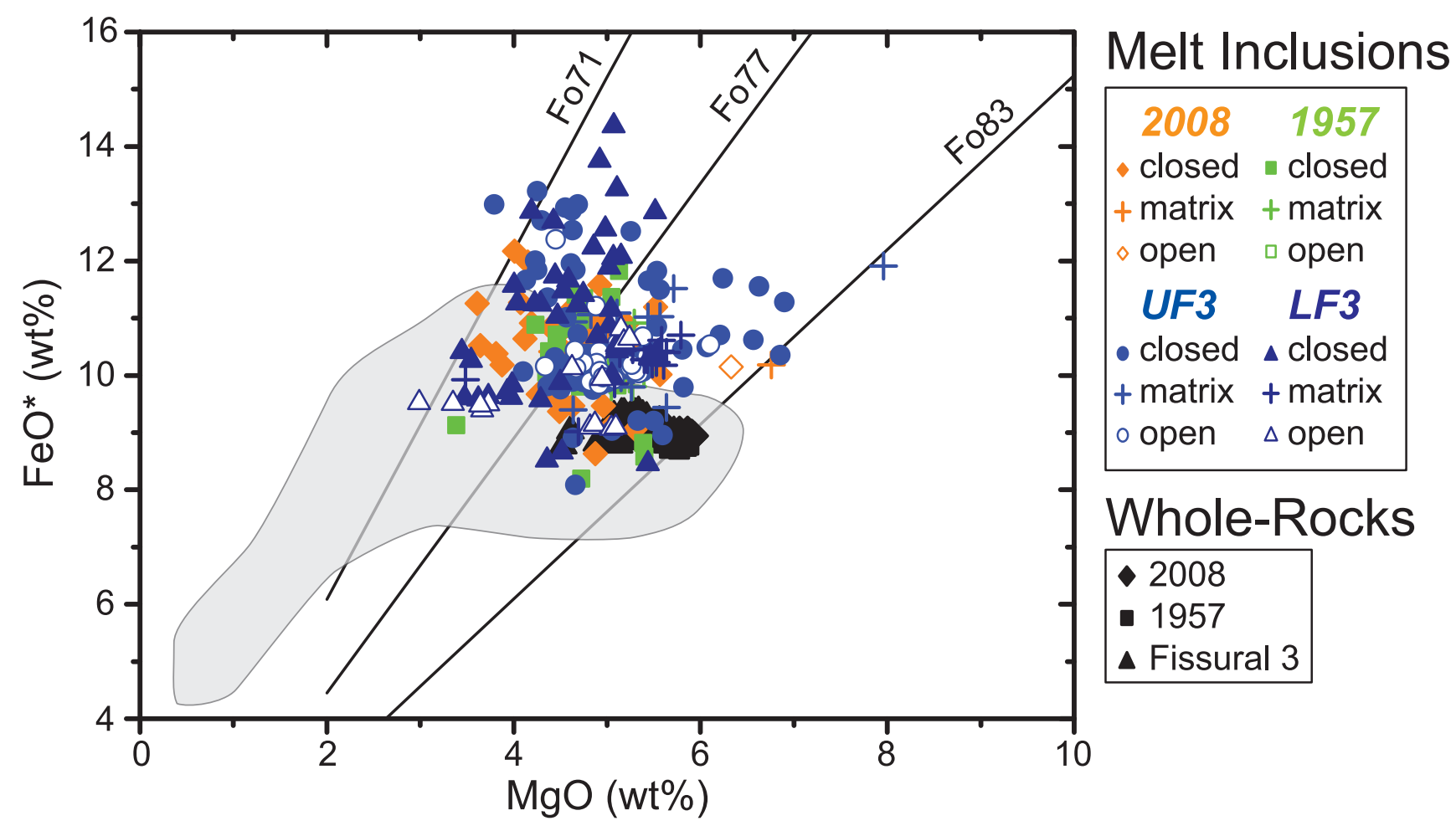

Figure 5 

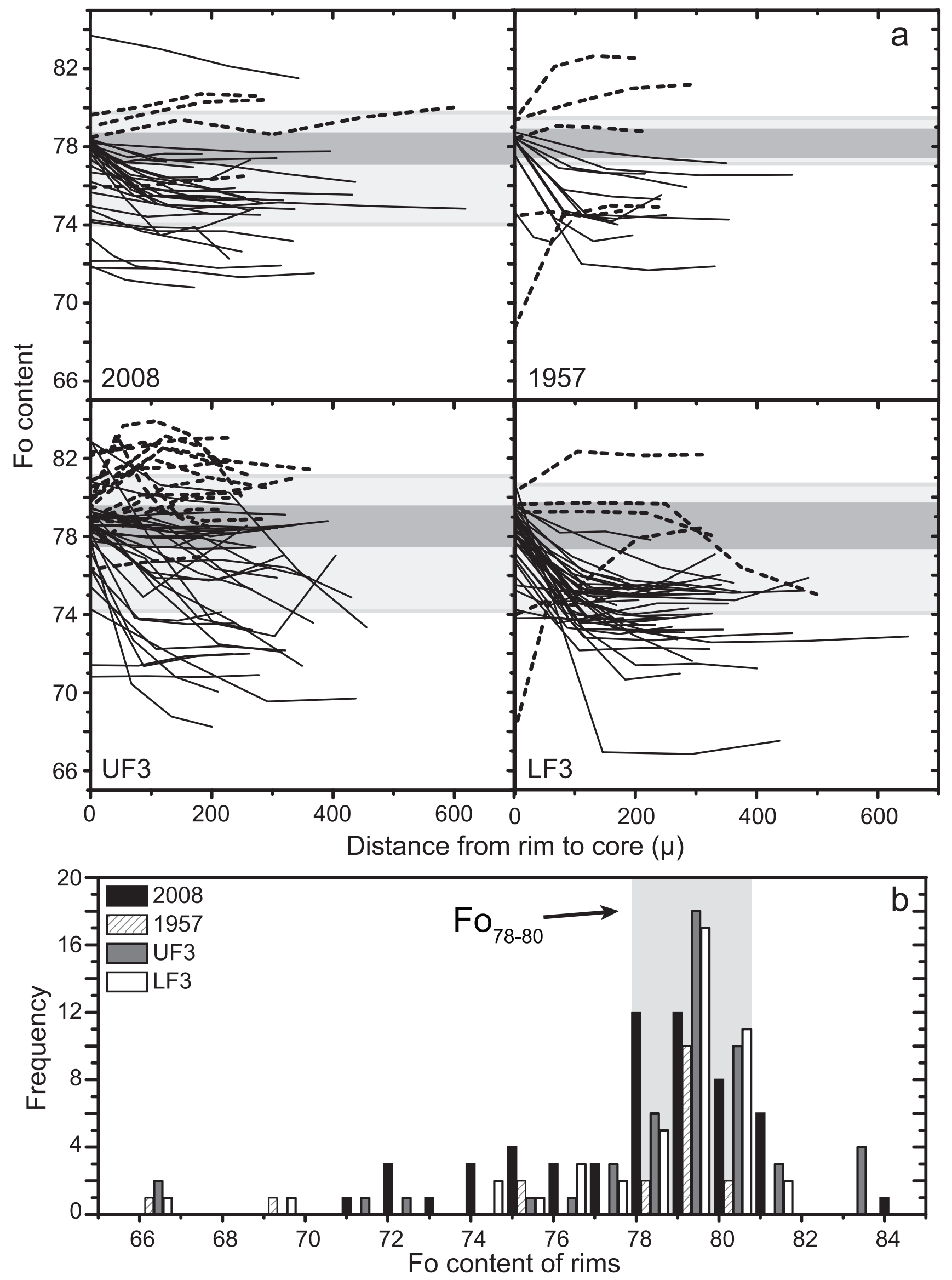

Figure 6 


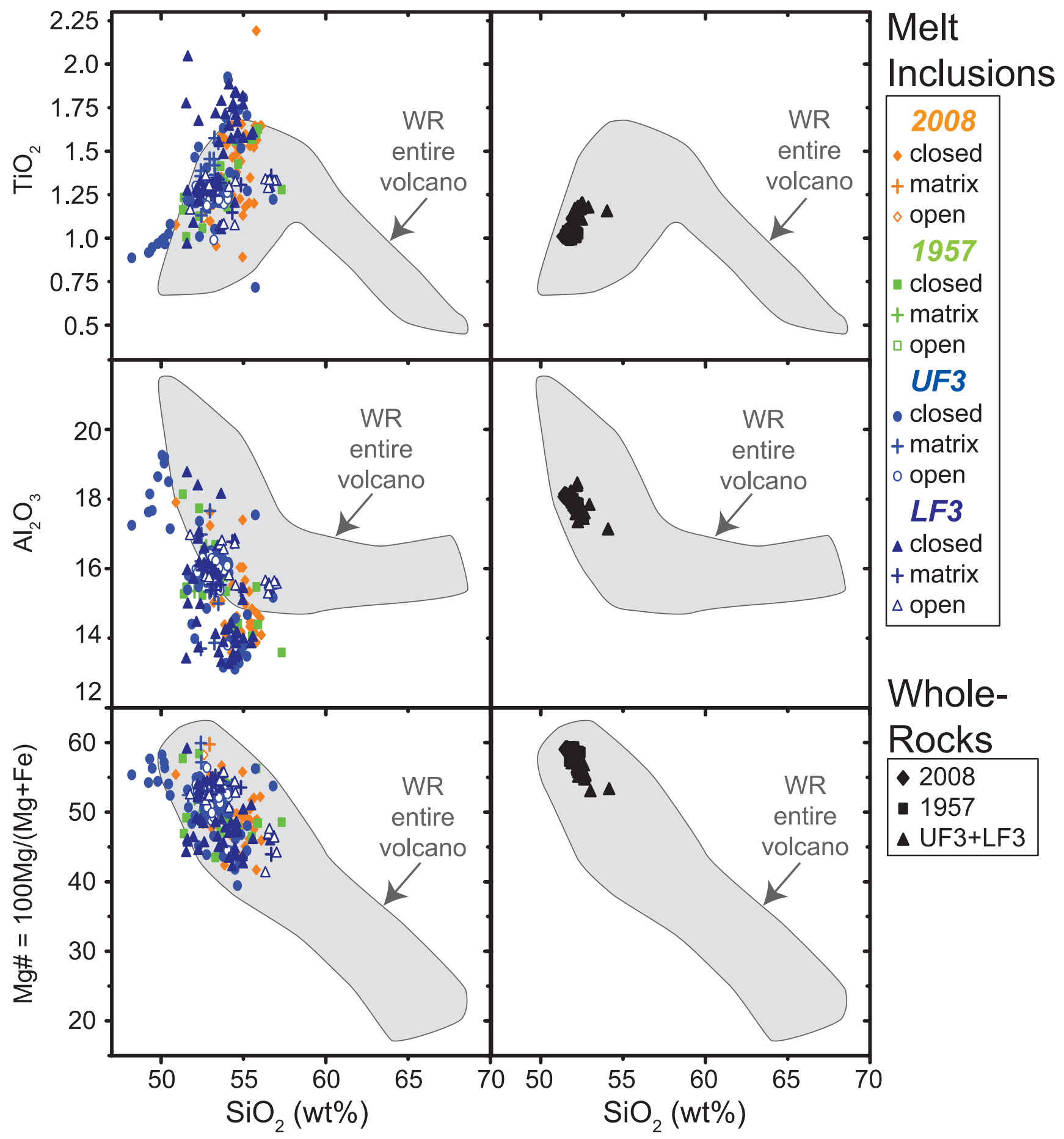

Figure 7 


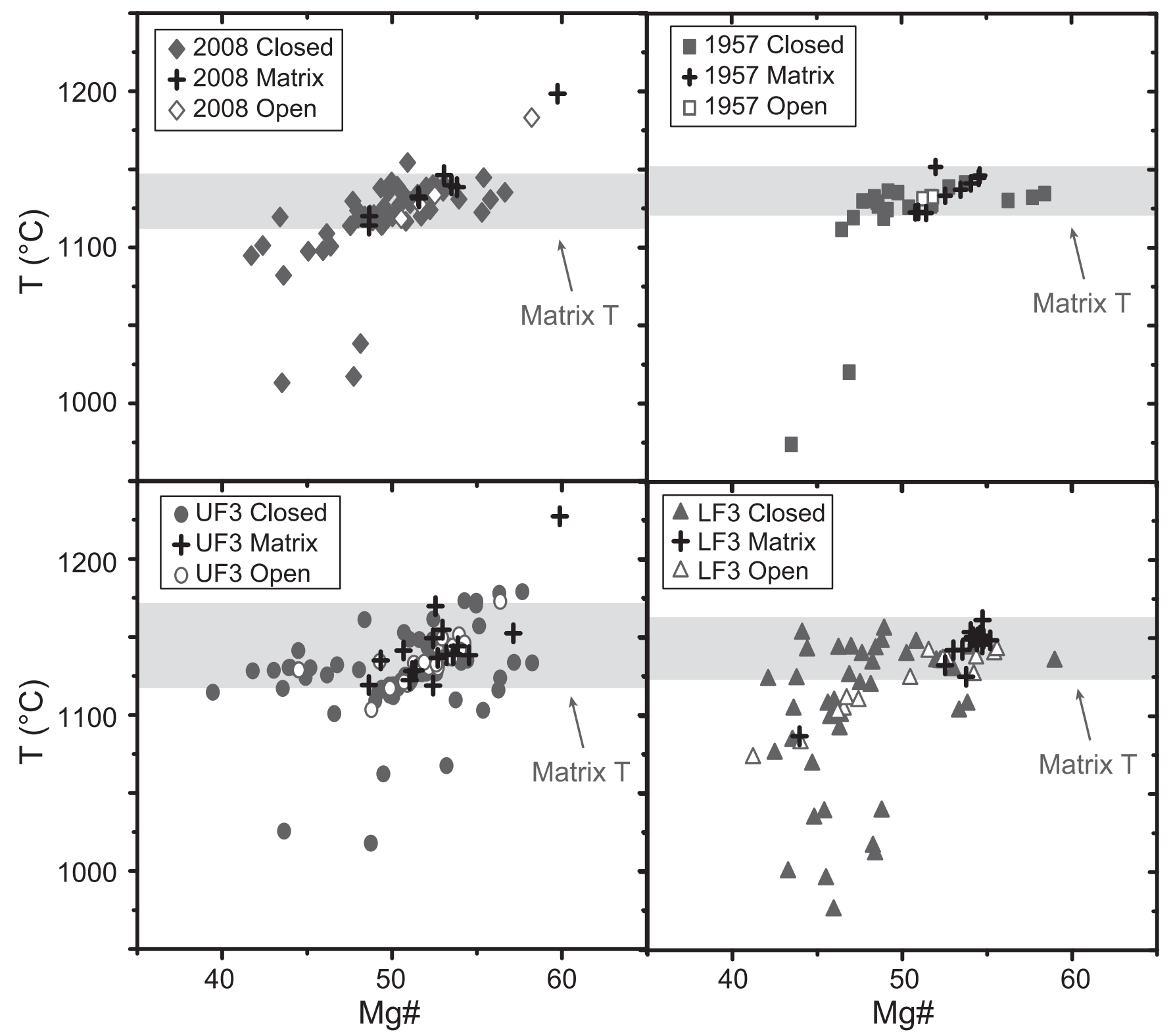

Figure 8 


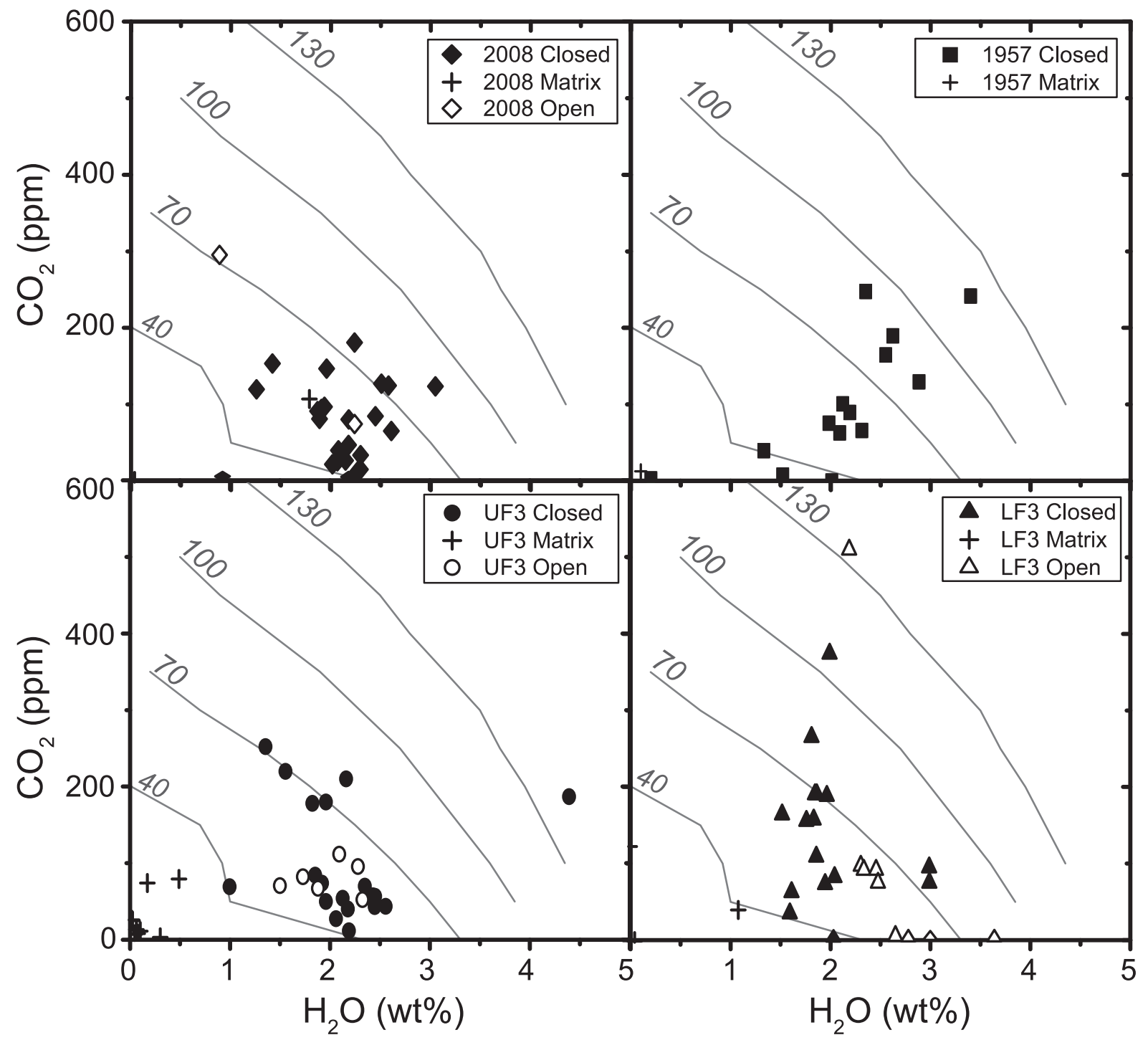

Figure 9 


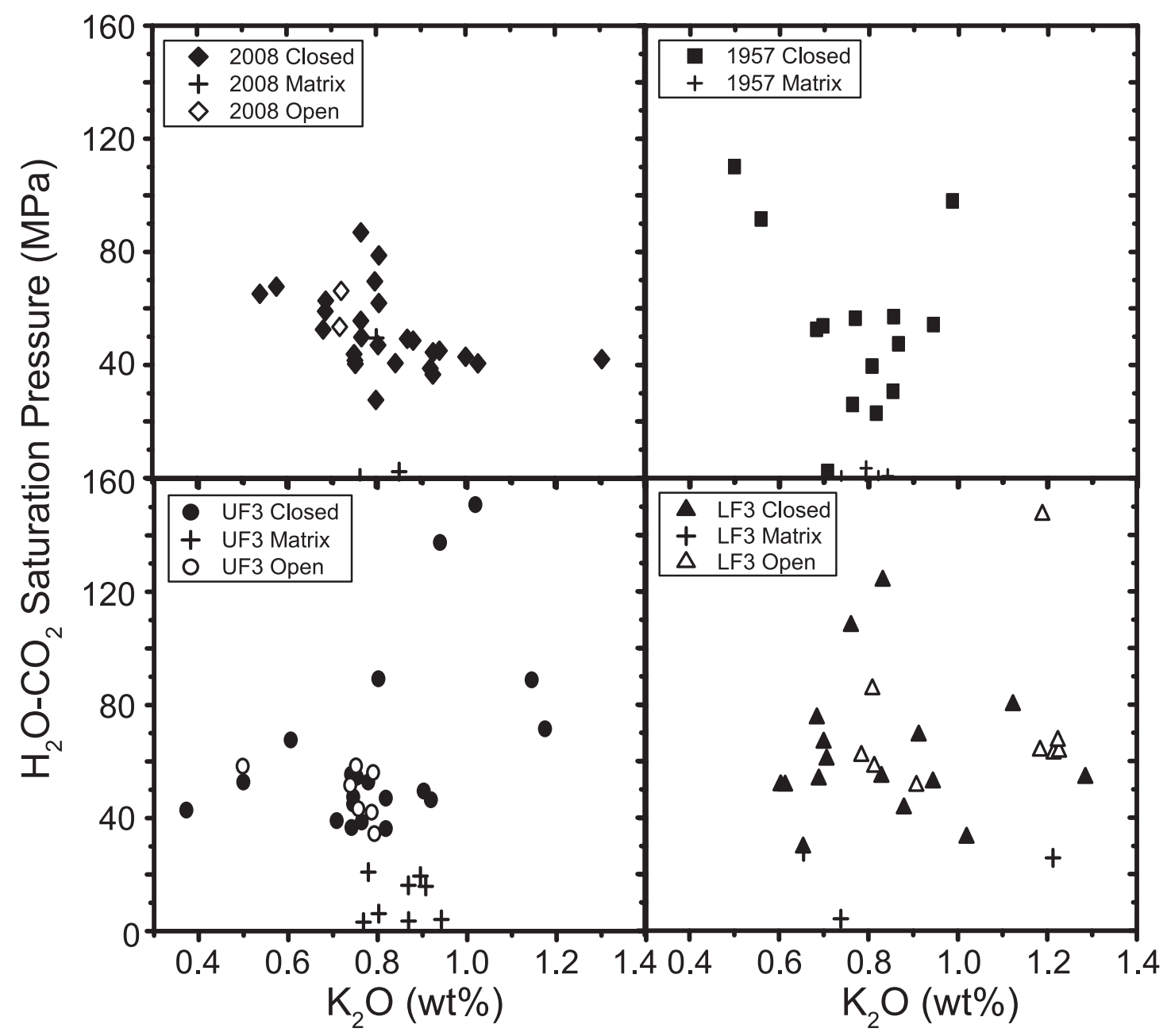

Figure 10 


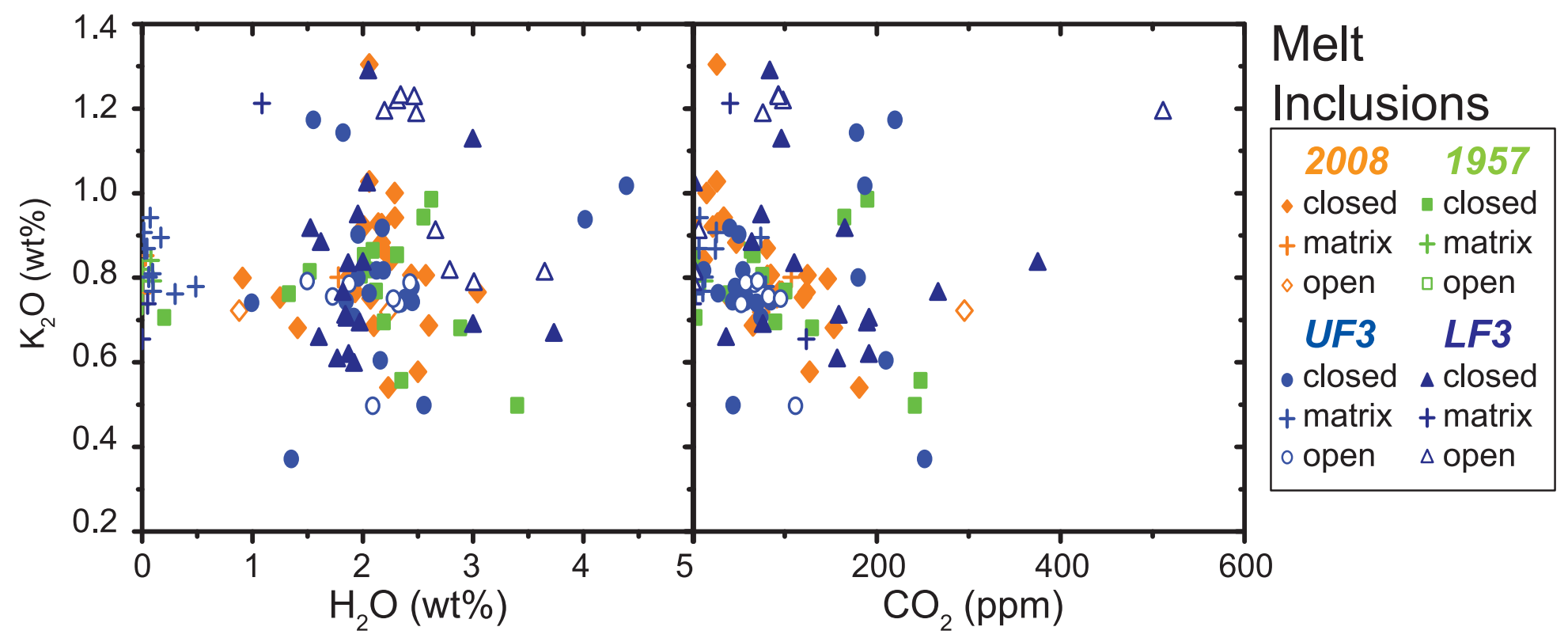

Figure 11 

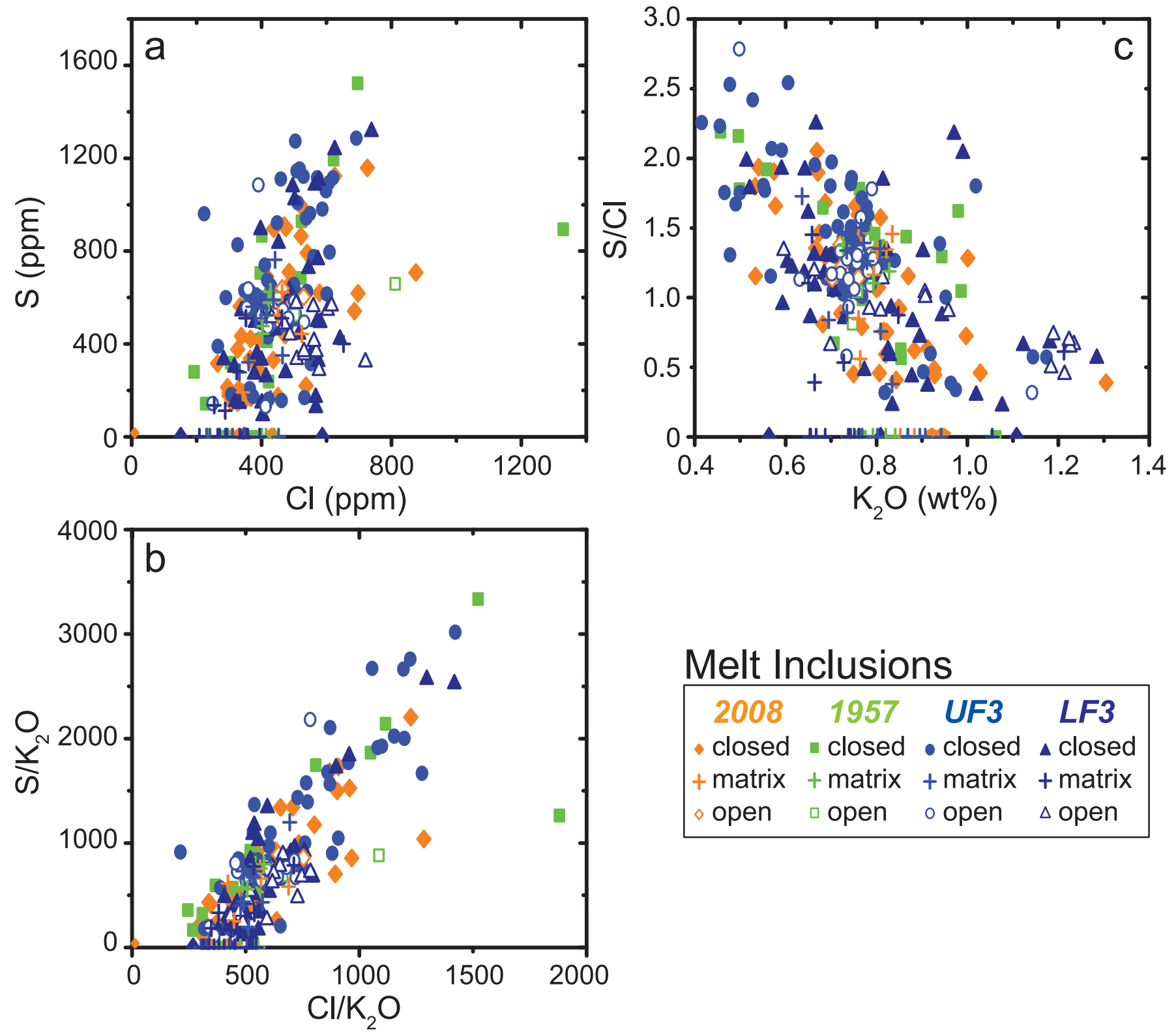

Melt Inclusions

\begin{tabular}{|cccc|}
\hline 2008 & 1957 & UF3 & LF3 \\
- closed & - closed & •closed & A closed \\
+ matrix & + matrix & + matrix & + matrix \\
open & open & o open & $\Delta$ open \\
\hline
\end{tabular}

Figure 12 


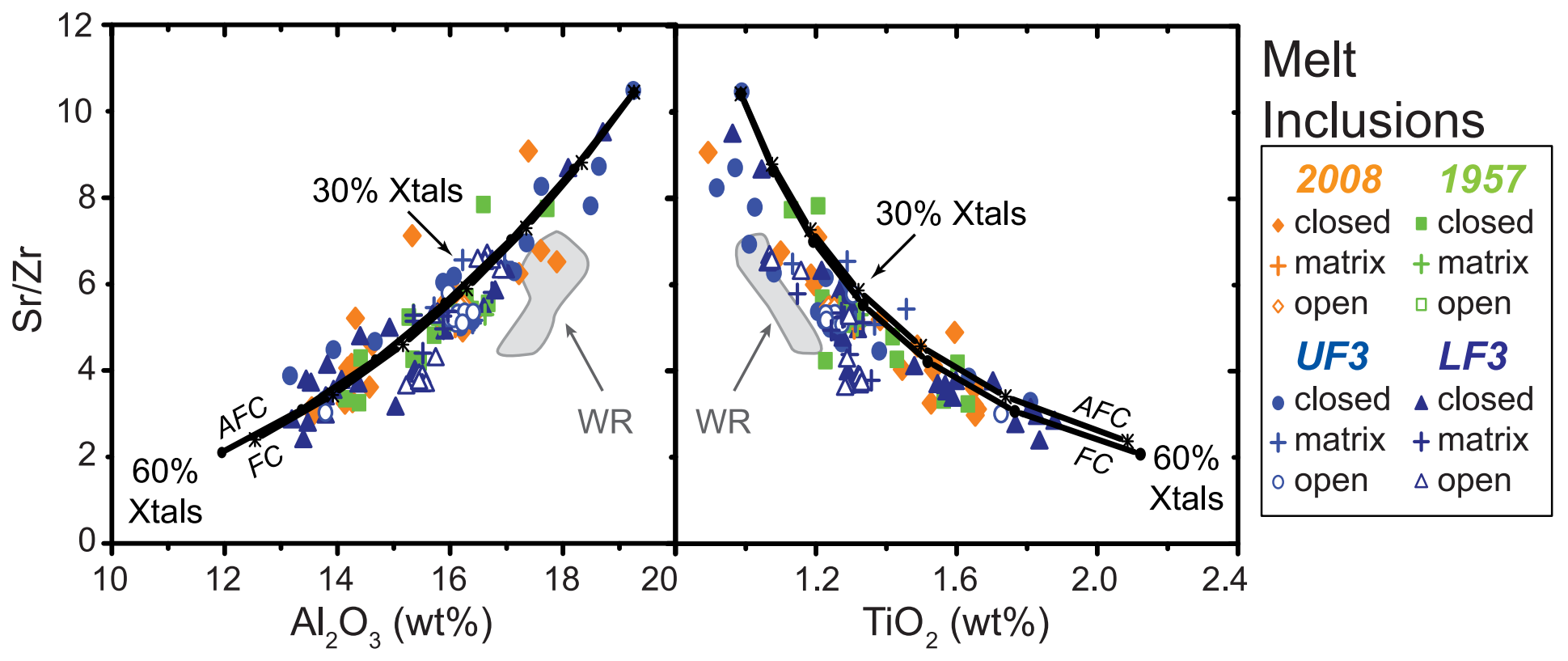

Figure 13 


\section{Main Summit Vent}

(2008, 1957)

Secondary Summit

Vent (1957)

$\mathrm{S}$

$1 \mathrm{~km}$

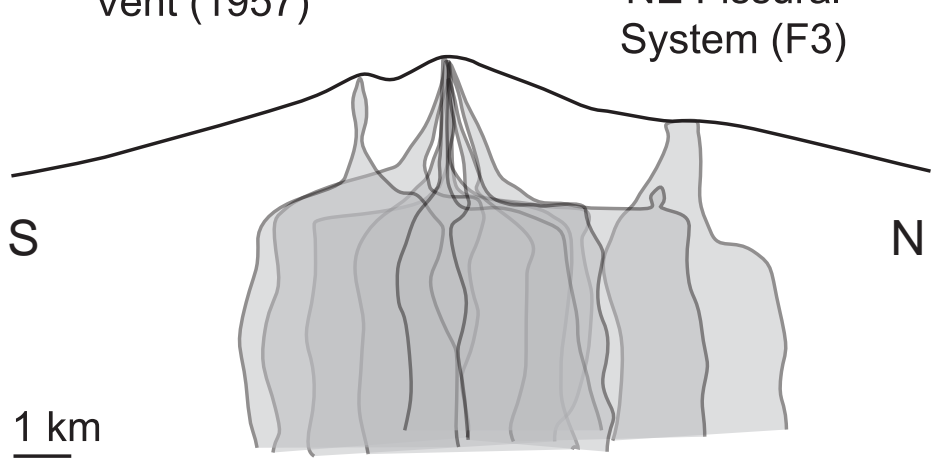

Main Summit Vent (2008, 1957)

NE Fissural

System (F3)

N E

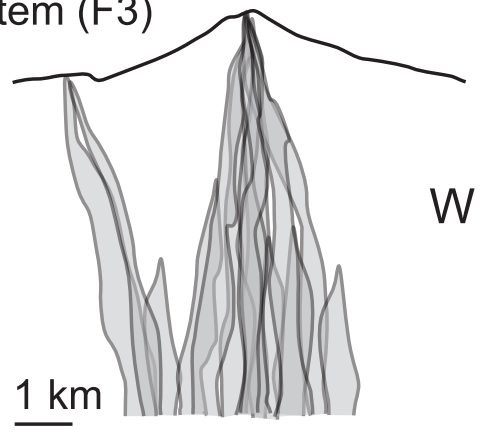

Figure 14 